\title{
A PRÁtiCA MÉDICA NO PROGRAMA DE SAÚdE DA FAMÍLIA E SUA CONTRIBUIÇÃO PARA MUDANÇA DO MODELO TECNOASSISTENCIAL EM SAÚDE: \\ LIMITES E POSSIBILIDADES
}

\author{
LUIZA MARIA DE CASTRO AUGUSTO ALVARENGA
}

Dissertação apresentada ao Programa de Pós-graduação em Saúde Pública da Faculdade de Saúde Pública da Universidade de São Paulo para obtenção do título de Mestre em Saúde Pública.

Área de concentração: Serviços de Saúde Pública.

ORIENTADOR: PROF. DRA. CLEIDE LAVIERI MARTINS

São Paulo 


\section{RESUMO}

Alvarenga LMCA-. A prática médica no programa de saúde da família e sua contribuição para mudança do modelo tecnoassistencial em saúde. Limites e Possibilidades. São Paulo; 2004. (Dissertação de Mestrado - Faculdade de Saúde Pública da USP)

A partir do Séc.XX, os modelos de organização do Sistema de Saúde no Brasil obedeceram à lógica do paradigma unicausal da medicina moderna, direcionando suas atividades em consonância com as expectativas das classes dominantes, em diferentes conjunturas políticas. Os modelos tecnoassistenciais unicausais organizaram as práticas de saúde antepondo barreiras entre o agente e o hospedeiro como no Modelo Campanhista e Modelo Médico Sanitarista ou tratando o indivíduo doente onde sua maior expressão se deu na oferta de consultas médicas sob a gerência do Instituto Nacional de Previdência Social (Modelo Médico Privatista) . O Movimento da Reforma Sanitária Brasileira, inscreveu na Constituição do Brasil de 1988 o direito à saúde, o Sistema Único de Saúde e os princípios que devem nortear a formulação de um novo modelo de saúde, entre eles: democracia, descentralização, hierarquização, resolutividade, admitindo a causalidade complexa do adoecer que necessita de ações intersetoriais para construção da saúde com mudança das práticas de saúde. Em 1993 o Governo Brasileiro estabeleceu o Programa de Saúde da Família (PSF) como estratégia para a construção do novo modelo e a cidade de Vitória seguindo as orientações do governo federal tem investido recursos técnicos e financeiros para ampliação de cobertura do Programa. Adotando-se a referência teórica de modelo tecnoassistencial adotado MEHRY, CECÍLIO e NOGUEIRA em 1991, este estudo tem por objetivo identificar nas atividades dos médicos, elementos que sinalizem a operacionalização de conceitos fundamentais para a mudança do modelo. Esta pesquisa é um estudo de caso de uma Região de Saúde da cidade de Vitória que utilizando a abordagem qualitativa na coleta e análise dos relatos de 7 médicos entrevistados evidenciou que a prática dos médicos do PSF reproduzem o Modelo Médico Sanitarista e Médico Privatista, na dependência do sujeito que opera as práticas, sua formação, sua subjetividade e também na dependência do contexto em que o PSF se desenvolve.

Descritores: Modelo Tecnoassistencial em Saúde, Prática Médica, Programa de Saúde da Família . 


\section{ÍNDICE}

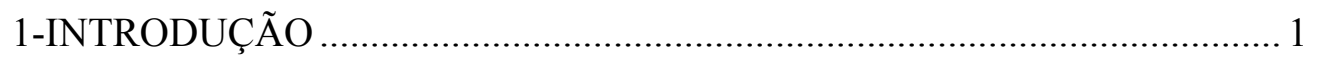

1.1- Os modelos tecnoassistenciais no Brasil do Séc. XX .................................. 5

1.2- Um Modelo para o Sistema Único de Saúde. ....................................... 13

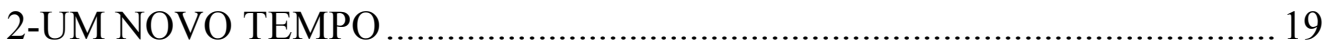

2.1- O Programa de Saúde da Família............................................................ 19

2.2- A História das Mudanças no Município de Vitória ................................ 24

2.3- Saúde da Família - Estratégia para o Novo Milênio ................................ 30

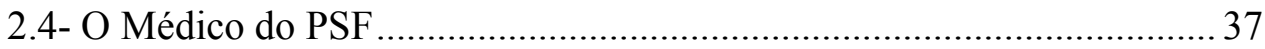

3.- IDENTIFICAÇÃO DO PROBLEMA ….................................................. 47

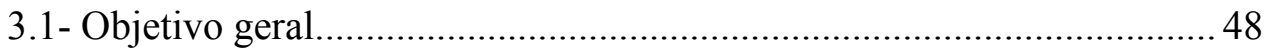

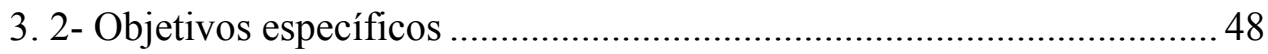

4 - O CAMINHO METODOLÓGICO ….......................................................... 49

4.1- Caracterização do local de estudo ......................................................... 51

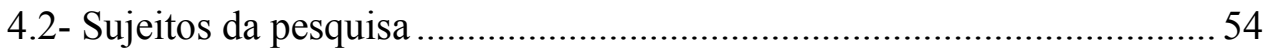

4.3- Procedimentos para coleta de dados .................................................... 55

4.4- Instrumentos de coleta de dados .............................................................. 56

5 - ANÁLISE E DISCUSSÃO DOS RESULTADOS ........................................58

5.1- Características dos entrevistados ....................................................... 58

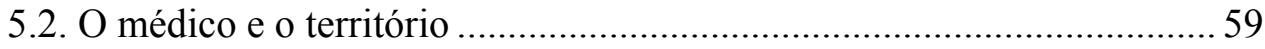

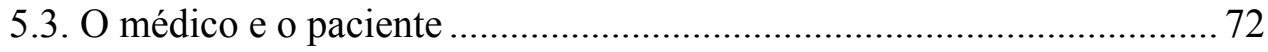

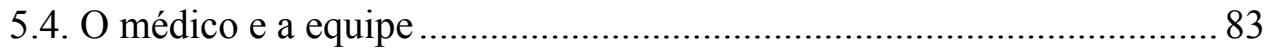

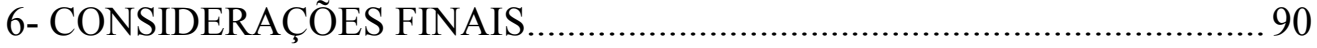

7- REFERÊNCIAS BIBLIOGRÁFICAS........................................................ 95

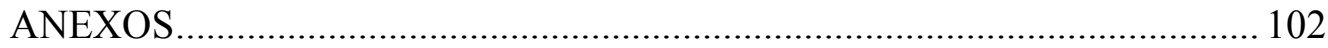

Anexo 1- Regiões e Serviços de saúde de Vitória ............................................. 103

Anexo 2- Bairros da região de São Pedro ........................................................... 104

Anexo 3- Termo de Consentimento Livre e Esclarecido .................................... 105

Anexo 4- Perguntas norteadoras ................................................................. 106 
Autorizo, exclusivamente para fins acadêmicos, a reprodução total ou parcial desta dissertação, por processo fotocopiadores 


\section{DEDICATÓRIA}

Aos sanitaristas pioneiros do Estado do Espírito Santo

Ely Leonardo de Castro

Itamar Soares Dias

Marlene Maia

Nathanael Rauta Ramos

Aos sanitaristas pioneiros do Município de Vitória

Eloá e Tânia - Área I

Edilene e Márcia de Jesus - Área II

Marli - Área III

Ana Lúcia - Área IV

Eider e Elizabeth - Área V

Iva e Vera - Área VI

Josilda e Sonia - Área VII 


\section{AGRADECIMENTOS}

A orientação da Dra. Cleide Laviere Martins.

A Secretaria Estadual de Saúde e seu Secretário de Saúde João Felício Escárdua, Escola Superior de Medicina da Santa Casa de Misericórdia - EMESCAM, Secretaria Municipal de Saúde de Vitória e seu Sub - Secretário Dr. Francisco José Dias da Silva.

Ao Coordenador do Programa de Educação Continuada da SEMUS- Vitória Dr. Hélio Andreollo.

Aos amigos do Departamento de Saúde Coletiva da EMESCAM.

Aos médicos entrevistados

A Arlindo, Ana Luiza, Gabriel e Henrique 


\section{SUMMARY}

Since the XX century, the models of organization of the Health System in Brazil obey to the logic of the unique cause paradigm of the modern medicine, directing his activities in consonance with the expectations of the dominant classes, on different politic contexts. The technique and assistencial model and the unique cause organized the health parctices putting barriers between the agent and the host as in the Campaing Model and the Medic Sanitarist Model or treating the sick one. It,s biggest expression was with the offering of medical appointments with the management of the National Social Welfare Institute. The Brazilian Sanitary Reformation Movement booked in Brazilian Constitution of 1988 the right of health, The Unique Health System and the principles that should lead the formulation of a new health system, between then: democracy, decentralization, hierarchy, resolution, admitting the complex causality of sicken that requires actions betwueen different sectors to build the health with changes on health practices. On 1994, the Brazilian government established the Program of Family Health (PFH) as an strategy to form the new model and the city of Vitória, following the orientations of the federal government, has invested financial riches to enlarge the program. Using the theoretical reference of the construction of the technique and assistencial model used by MEHRY, CECILIO and NOGUEIRA on 1991, this study has as an objective identify the elements on the medical practices that sign and characterize the practice of fundamental concepts in the model change. This is a Case Study Research of an area of Vitória that using a quality approach in the collect of the reports, showed that the medical practices of the PFH reproduce the Medical Sanitary Model and the Medical Privativist, depending on as much the subject that does the practice, his formation, his subjective and also depending on the context that PFH develops itself.

Key Words: Medical Practice, Program of Family Health , Health Model 


\section{INTRODUÇÃO}

A estrutura dos serviços de saúde e a oferta de cuidados médicos têm se modificado na última década, mas ainda não está consolidado o sistema de saúde estabelecido na Constituição Federal do Brasil de 1988, que teve suas bases conceituais estabelecidas na década de setenta.

O Movimento da Reforma Sanitária que se desenvolveu no Brasil, na segunda metade da década de setenta, possibilitou a formulação de um projeto de reforma sanitária, fazendo parte da redemocratização do país. Este movimento, formado por "um conjunto organizado de pessoas e grupos partidários ou não, articulados ao redor de um projeto" (ESCOREL 1988, p.5), ao analisar a grave situação sanitária que se instalou no país, questionou-se a concepção de saúde dominante na época, além de apontar o agravamento da desigualdade social e a incapacidade dos serviços de saúde contribuírem para a saúde da população. O Movimento tornou clara a necessidade de mudanças na sociedade que favorecessem a melhoria das condições de vida dos brasileiros e ajudou a definir o texto da saúde, construído pela Assembléia Nacional Constituinte, quando elegeu como questões centrais à Reforma Sanitária Brasileira um quadro de propostas proveniente da $8^{\mathrm{a}}$ Conferência Nacional de Saúde $\left(8^{\mathrm{a}} \mathrm{CNS}\right)$, realizada em 1986. De acordo com o relatório final desta conferência, deveriam estar assegurados constitucionalmente (RODRIGUES NETO 1997, p.70):

- $\quad$ O conceito de saúde, referido não apenas à assistência médica, mas relacionado com todos os seus determinantes e condicionantes, como: trabalho, salário, alimentação, transporte, meio ambiente, entre outros.

- $\quad \mathrm{O}$ direito universal e igualitário à saúde.

- $\quad$ O dever do Estado na promoção, proteção e recuperação da saúde.

- $\quad$ A natureza pública das ações e serviços de saúde. 
- A organização das ações do Estado em uma rede regionalizada e hierarquizada, constituindo um Sistema Único de Saúde gratuito, descentralizado para Estados e Municípios, sob controle social.

- Subordinação do setor privado às normas do Sistema Único e, quando necessário, contratado sob as normas do direito público; diretriz de estatização progressiva.

- Desvinculação do Sistema de Previdência Social, com financiamento autônomo, preservada a gratuidade na substituição das fontes previdenciárias, estabelecimento de pisos e gastos.

Após a promulgação da Constituição Brasileira, foram estabelecidas as bases fundamentais para a organização do Sistema Único de Saúde (SUS), definindo-o como único, estabelecendo o princípio do direito do cidadão e dever do Estado e as diretrizes de universalidade, igualdade e integralidade, inscritos nos artigos de número 196 a 200 (CAMPOS 1994 e PAIM 1997).

Nos anos noventa, a viabilização do Sistema de Saúde Brasileiro foi garantida juridicamente nas Leis Orgânicas da Saúde 8080 e 8142, no Decreto nº 99438/90 e nas Normas Operacionais Básicas (NOBs). Estas Normas conduziram o sistema anterior, caracterizado pela centralização política administrativa e financeira, para um sistema de saúde organizado pelos princípios da regionalização e hierarquização, resolubilidade, descentralização, participação popular e complementaridade do setor privado, onde os municípios brasileiros tornaram-se instâncias privilegiadas de responsabilidade sanitária pelas populações.

Na descentralização, as NOB's 91, 93 e 96 reforçaram o poder de regulação do nível federal do Sistema Nacional de Saúde, mas elegeram os gestores municipais como atores principais na construção do SUS, desempenhando novos papéis em dois eixos principais: 
descentralização do poder (Política Municipal de Saúde) e descentralização técnica, tendo como suporte uma estrutura organizacional (Secretaria Municipal de Saúde) que respondesse aos desafios da construção de um novo modelo de atenção à saúde.

Foi na NOB-SUS de 1996 que a perspectiva da descentralização financeira consolidouse, estimulando os municípios a assumirem, inicialmente, a organização da rede básica de saúde, para a qual receberiam recursos de custeio para um conjunto limitado de procedimentos $(\mathrm{MS} / 2002)$.

Ao se municipalizarem as ações e os serviços de saúde, apesar das palavras claras nas leis, era de difícil compreensão de que maneira, como e o que de novo deveria ser construído para a saúde da população. Os primeiros modelos receberam influência da produção de organismos internacionais, principalmente a Organização Panamericana da Saúde (OPS) e da reforma sanitária italiana (CAMPOS 1994).

Desde o início do movimento pela reforma sanitária brasileira, foram motivos de muita reflexão quais práticas deveriam ser introduzidas ou modificadas para a construção do Modelo de Saúde para o Brasil, e ainda existe dificuldade de entendimento por parte de gestores municipais e profissionais de saúde que trabalham no Estado do Espírito Santo, na abordagem sobre que práticas são para o SUS, quais práticas devem ser incorporadas para irem além de um modelo curativo e individual e produzirem intervenções sobre agravos, riscos e determinantes, como está na LEI 8080, que explicita os preceitos Constitucionais.

Para ESCOREL (1988), o próprio movimento sanitário caracterizou um conjunto de práticas: a teórica, a ideológica e a política. PAIM (1997), ao caracterizar as práticas de saúde, refere que estas concretizam-se no plano técnico-institucional, onde são o elo de ligação entre os cidadãos, a burocracia e os agentes das práticas de saúde, e é neste plano de atuação que a Reforma Sanitária se consolidará. 
A forma de organização das práticas de saúde faz-se segundo um modelo que será cada vez mais distante do modelo hegemônico quando são a expressão concreta de um novo entendimento da causa de adoecimento. Sendo assim expressam-se em novas práticas, diferentes das hegemônicas, direcionadas para a cura.

Nesta dimensão, a fundamentação da estrutura do Modelo dá-se na concepção de causalidade do processo saúde-doença, que percorre a história, mostra-nos a mudança das ações a partir da capacidade explicativa dos problemas. A consolidação do modelo faz-se a partir da política governamental onde o modelo é apresentado, fazendo parte das políticas públicas.

As muitas definições de modelos, adotadas pelos serviços de saúde, baseiam-se em uma posição fragmentária de aspectos do modelo, levando a uma generalização imprópria como: modelo médico curativo, modelo médico preventivo, modelo clínico, modelo epidemiológico, modelo hospitalocêntrico e outras designações.

Em CAMPOS (1998), torna-se claro o papel de uma política pública na organização de um modelo. Enfatiza-se o papel do Estado e dos serviços de saúde na decisão de como as ações de saúde são produzidas e distribuídas para uma população

(p. 53).

A complexidade dos fatores envolvidos na construção de modelos foi abordada por MERHY et al (2002), quando definiu que: “Os modelos assistenciais são produtos sóciohistóricos e, portanto, se viabilizam a partir de um certo ambiente institucional propulsor de determinada política para o setor saúde. Um certo conjunto de idéias e diferentes modos de 
intervenção em serviço (tecnologias) são chamadas a estruturarem o modelo assistencial" (p.102).

As denominações de Modelo Assistencial de Saúde, Modelo de Atenção à Saúde ou Modelo Tecnoassistencial em Saúde diferenciam-se na abrangência das variáveis envolvidas na construção do modelo, sendo melhor denominado de Modelo Tecnoassistencial, conforme argumentado por MEHRY, CECÍLIO e NOGUEIRA, em 1991. Sob esta denominação, os seguintes elementos se destacam:

- $\quad$ a concepção do problema;

- $\quad$ a estratégia de intervenção a ser utilizada;

- a base tecnológica de suporte do modelo; e

- os saberes, os trabalhadores, as instituições, os interesses dos grupos envolvidos.

Tal referencial teórico fornece um conjunto de elementos que dão suporte e forma às práticas de saúde e às características peculiares dos diferentes modelos.

\subsection{Os modelos tecnoassistenciais no Brasil do Séc. XX}

Na história brasileira, os Modelos Tecnoassistenciais de Saúde, a partir dos séc. XX, foram sendo organizados em resposta a situações de exigências das classes dominantes, mas, a partir de 1988, o desenvolvimento do Sistema de Saúde brasileiro está garantido como um direito dos cidadãos.

Até a metade do século passado, a economia brasileira, agroexploradora, precisava de espaços livres das epidemias para circulação e exportação das mercadorias. O modelo de saúde então adotado pelo Estado Oligárquico teve como prática de saúde as campanhas 
sanitárias e o saneamento urbano, pautados na unicausalidade biologicista e na teoria do germe, não se preocupando com a estrutura de morbimortalidade da população. O Modelo Campanhista controlou as principais epidemias urbanas, como a febre amarela e a febre tifóide, e favoreceu o desenvolvimento dos principais centros exportadores, comerciais e em incipiente processo de industrialização.

Um novo modelo de saúde, defendido por Geraldo Horácio de Paula Souza, é apresentado na década de vinte, durante o Congresso da Sociedade Brasileira de Higiene, introduzindo o enfoque da educação em saúde como instrumento para o desenvolvimento da consciência sanitária das populações que, quando aliada ao saneamento ambiental, possibilita a saúde plena.

Nos Anais do $1^{\circ}$ Congresso de Higiene (1923), a proposta de Paula Souza expõe a necessidade de implantação de serviços de saúde locais e permanentes, nos municípios, que deveriam suceder a uma campanha. Sua justificativa baseava-se na dificuldade de se manter e melhorar os resultados alcançados nas Campanhas Sanitárias que, sendo pontuais, não foram capazes de resolver os problemas do saneamento rural. Nas palavras do autor: "dentro do espaço de 3 a 4 anos, a população volta ao estado de infecção" (p.48).

Os serviços locais, organizados em Postos Municipais Permanentes, teriam as seguintes atribuições: (p.50)

1- Educação Sanitária - "é a de maior importância na solução do saneamento. Por meio de Conferências Públicas e Escolares, Palestras particulares, demonstrações microscópicas, projeções físicas e animadas"

2- Tratamento das endemias 
3- Profilaxia das endemias - latrinas

4- Inspeções escolares

5- Laboratórios

6- Combate às epidemias

7- Profilaxia das epidemias

8- Vacinas e soros

9- Policiamento sanitário - "vistorias nas casas"

As ações propostas estariam organizadas em redes locais permanentes, isto é, uma rede de postos descentralizados nos municípios e com áreas de abrangência definidas. A doença considerada como resultante da presença do agente externo (bacteriano) seria prevenida por atitudes higiênicas dos indivíduos, sendo este o responsável pelo seu próprio adoecimento. A ação médica seria apenas coadjuvante da educação em saúde, considerada a causa básica de adoecimento. Esta concepção de manutenção da saúde, e não o combate exclusivo da doença, caracterizou a corrente médico-sanitária.

Para MERHY (1992), a prática de saúde da Rede Local Permanente, a partir da corrente médico-sanitária, caracterizou a organização de serviços no Modelo de Saúde Médico-Sanitário e foram de grande importância as noções de prevenção e promoção introduzidas por este modelo. As atribuições dos profissionais médicos estavam direcionadas para a saúde pública e não para a assistência médica, sendo necessário que as normas sobre o ambiente externo fossem obedecidas para proteção e promoção da saúde. O médico, auxiliado pela educação sanitária, seria um educador em saúde e não um educador simplesmente (p.130, 131).

Ainda em MERHY (1992), outra forma de organização das ações de saúde toma visibilidade política na década de 30 , por defesa de alguns sanitaristas que estavam no 
aparelho estatal. Esta nova organização diferenciava-se das Redes Locais Permanentes por considerar que cada problema de saúde pública deveria estar sob a responsabilidade de serviços especializados. Para cada causa específica de adoecimento, valorizava-se o agente externo e a educação médico-sanitária, mas a complexidade dos problemas de saúde e a divisão do trabalho justificavam a necessidade de especialistas (p. 103). Para os adeptos da organização especializada dos serviços de saúde, a figura do médico passa a estar agora envolvida com a assistência médica aos enfermos e nas ações de promoção e prevenção da saúde, ficando estabelecido um modelo tecnoassistencial denominado pelo autor de Modelo Vertical Permanente Especializado.

Segundo FARIA (2002), esta diferença não se traduziu por diferentes modelos institucionais de saúde pública, mas sim por uma rivalidade política dos sanitaristas que lideravam o cenário paulista, uns em defesa do aprimoramento da organização do modelo campanhista e outros em defesa da descentralização. Em MERHY (1992), os serviços especializados tornaram-se um paradigma de organização técno-assistencial quando o governo direcionou grande parte dos gastos estaduais para os programas de combate á Lepra e á Tuberculose.

O Golpe Militar de 1937 remete a política de saúde pública para a totalidade dos programas verticais. Em 1942, para que se estendesse a cobertura dos programas de prevenção, houve necessidade de uma rede de serviços que se consolidou com a incorporação dos Postos de Saúde e outras estruturas já existentes, caracterizando a Rede Local Verticalizada. Os Postos de Saúde já tinham responsabilidade no controle das doenças transmissíveis, na higiene do trabalho e na liberação de exames periódicos desde 1938, mas, para o desenvolvimento dos programas, foram agregados aos médicos e às enfermeiras as visitadoras sanitárias e outros profissionais como microscopistas, serventes e inspetores sanitários (MEHRY 1992). 
Para responder à economia industrializada, a partir de 1930, novos rumos foram estabelecidos para o atendimento à população. Não havia espaço político para um modelo que operasse somente sobre uma população marginalizada, portanto era necessária uma ação que focalizasse a força de trabalho, conservando-a com um certo grau de higidez, através da intervenção individual. A industrialização deu assistência médica aos trabalhadores e às suas famílias, garantindo o desvio do enfoque coletivo das ações de saúde para o aspecto individual.

A partir de 1960, o governo brasileiro assumiu a assistência aos trabalhadores através da Previdência Social e criou-se uma extensa rede de prestação de serviços médicos que, na mesma década, necessitou de um investimento financeiro maior do que os recursos destinados à saúde pública.

Este Modelo Assistencial consolidou-se, em 1966, a partir da criação do Instituto Nacional de Previdência Social (INPS), com a prática de saúde focalizada na prática médica da escola flexeneriana, tendo como principais características:

- o privilégio da prática médica curativa, individual, assistencialista e especializada;

- $\quad$ a criação de um complexo médico-industrial, através da intervenção estatal; e

- o desenvolvimento de um padrão de organização da prática médica orientada em torno da lucratividade do setor saúde, propiciando a capitalização da medicina e o privilégio do produtor privado destes serviços.

Em 1975, o Governo do Brasil consolida a supremacia do Modelo Médico Assistencial Privatista com a promulgação da Lei $n^{\circ} 6229$ de 1975, que regulamentou o 
Sistema Nacional de Saúde e assegurou um fluxo de recursos financeiros regular e vinculado para a Previdência e Assistência Social, relegando o Ministério da Saúde à segundo plano.

$\mathrm{Na}$ segunda metade da década de setenta, este modelo já apresentava sinais de falência, e o abandono das ações de saúde pública contribuiu decisivamente para o agravamento da situação de saúde do povo brasileiro (RODRIGUES NETO 1997).

Mesmo com as mudanças organizacionais dos serviços, agregando tecnologias ou privilegiando categorias profissionais, todos os modelos operaram na causalidade única e no enfoque biologicista, ou antepondo barreiras que impedissem o encontro do homem com o agente, ou tratando uma alteração neste homem. A organização da prática médica nos moldes de consultas individuais para uma demanda espontânea caracterizou o Modelo Médico Assistencial Privatista, que agregou tecnologias com altos padrões de gastos sem, no entanto, causar impacto positivo na saúde das populações. A tecnificação do ato médico à procura da lesão fez a medicina científica articular-se progressivamente ao processo de industrialização e com aumento sucessivo dos custos. A medicina especializada aparece como a prática determinada tanto pelo desenvolvimento científico-tecnológico, como pela capitalização do setor.

Paralelamente ao desenvolvimento da Medicina Previdenciária no Brasil, um movimento de redefinição da prática médica com enfoque preventivo vinha tomando forma desde 1955 e 1956, quando a OPS, através de seminários com representantes das escolas médicas da América Latina, estimulou a criação de departamentos de medicina preventiva nas faculdades de medicina com o objetivo de produzir um novo tipo de médico que incorporasse na sua prática de rotina as ações de prevenção de doenças. Em 1968, um Comitê de Especialistas designados pela OPS elaborou um documento sobre o ensino da medicina preventiva e social e estabeleceu no conteúdo programático das escolas médicas as disciplinas de: medicina preventiva, epidemiologia, controle do ambiente, ciências da conduta, princípios de organização e 
administração e abordagem prática das ações preventivas frente aos indivíduos e às comunidades (AROUCA 1975). O discurso preventivista tinha, na teoria da multicausalidade, no conceito ecológico de saúde-doença e na história natural da doença, seus conceitos básicos.

A teoria da multicausalidade teve sua maior expressão em Brian MacMahon, que enriqueceu o conhecimento positivista da medicina e da epidemiologia, agregando fatores e cadeias de eventos na causalidade da doença. A interação entre os fatores envolvidos na causalidade das doenças, em várias fases do processo de adoecimento, foi apresentada por Leavel e Clarck como a História Natural da Doença (HND), (BREILH 1986). A ordenação de fatores preventivos em uma escala de tempo favoreceu a organização de uma prática médica preventiva que, mesmo admitindo fatores causais múltiplos: meio ambiente físico, biológico e socio-cultural, e incorporando-os na fase pré-patogênica, na fase patogênica, percorreu a fisiopatologia.

$\mathrm{Na}$ História Natural da Doença, a prática médica positivista tomou sentido coletivo em um conjunto de ações de promoção e prevenção, mas permaneceu prioritariamente individualizada na recuperação da saúde. Uma das críticas referidas por CAMARGO JR. (1997), ao apresentar a estrutura da doença formalizada na HND, em seu texto sobre a biomedicina, foi a abordagem de processo de adoecimento como tendo um transcurso temporal predeterminado.

$\mathrm{Na}$ década de sessenta, outra onda inovadora da prática médica estabeleceu-se, em programas alternativos, tendo, como maior difusora, a Organização Mundial da Saúde (OMS) e foi denominada de Medicina Comunitária. Esta proposta buscava orientar o modelo de organização dos serviços pela racionalidade e necessitou agregar conhecimentos relativos ao planejamento e à administração na área da saúde.

Segundo SILVA JR (1999), a Medicina Comunitária tinha como elementos estruturais:

- intervenções coletivas na prática médica;

- atividades de promoção, prevenção e cura 
- ações de saúde simplificadas;

- desconcentração de recursos por meio de uma organização hierarquizada;

- revisão crítica do uso de tecnologias da medicina flexeneriana;

- inclusão de práticas médicas alternativas;

- utilização de equipes de saúde com reestruturação da prática médica e de outras categorias;

- participação comunitária.

Em 1974, a OPS e a OMS posicionaram-se favoravelmente à transformação das práticas de saúde, a partir da transformação da prática médica, o que deveria ocorrer durante a formação profissional. Neste momento, é recuperado o discurso da medicina preventiva, mas com ênfase nas ciências da conduta: sociologia, antropologia, psicologia, que facilitariam a integração das equipes nas comunidades e o desenvolvimento dos programas de educação em saúde. A assistência médica convencional permaneceu como antes (PAIM 1997).

Desde sua origem, a Medicina Comunitária teve o objetivo de ampliar o acesso ao atendimento médico para os excluídos socialmente. Apesar de tratar o meio ambiente no processo de adoecimento, só considerou o meio imediato, físico, a-histórico e, mesmo agregando novos atores nas práticas de saúde, subordinou-os ao conhecimento médico científico (SILVA JR. 1999). Difundida nas universidades, foi implantada como projetospiloto em vários estados brasileiros e se tornou uma política de saúde após a Conferência sobre Cuidados Primários de Saúde em Alma Ata. Nesta Conferência, a OMS reafirma a saúde como direito do homem e de responsabilidade dos governos, reconhece a sua determinação intersetorial e estabelece a meta de Saúde Para Todos no Ano 2000.

As transformações que se verificaram no saber médico e na prática médica em cada modelo não foram conseqüências únicas das políticas de saúde desenvolvidas pelo Estado Brasileiro, mas estiveram sempre acompanhadas de uma política educacional, que ajudou a 
definir o tipo de médico que se precisava em cada momento e que marcaram um novo tempo quando romperam práticas que vinham sendo desenvolvidas. LUZ (1986), ao discutir as instituições médicas no Brasil, responsabiliza a política de saúde previdenciária e a política de educação voltada para especialização e tecnificação, como indutoras da prática médica dominante a partir dos anos setenta.

\subsection{Um Modelo para o Sistema Único de Saúde}

Como mais um ciclo de mudanças para a organização do sistema de saúde brasileiro, o que ainda estamos vivendo e não está consolidado em suas características principais é o modelo apoiado no referencial de saberes da saúde coletiva.

Para Nunes, citado por CAMPOS (2000, p.222), o campo da saúde coletiva surgiu quando um grupo de profissionais brasileiros, da área da medicina preventiva e da saúde pública, procurou estabelecer uma orientação teórica, metodológica e política que privilegiasse o social como categoria de análise. O paradigma alternativo da saúde coletiva ficou centrado em dois conceitos: determinação social das doenças e o processo de trabalho em saúde, o que contribuiu decisivamente na proposta de construção do SUS (PAIM 1997).

Ao se admitir que o adoecimento não mais seria explicado exclusivamente pela dimensão biológica e ecológica, mas contextualizado social e historicamente, as práticas de saúde deveriam ser ampliadas, abrangendo toda a realidade que transcende o setor saúde para que, assim, promovessem alterações profundas na sociedade.

O campo da saúde coletiva desenvolveu-se por dois caminhos, um teórico e outro político, que se externalizou no Movimento da Reforma Sanitária Brasileira, com propostas de redemocratização da sociedade e que teve como marco a $8^{\circ}$ Conferência Nacional de Saúde. 
Esta Conferência deu as bases para construção de uma nova política de saúde, enumerando diretrizes gerais a serem seguidas:

- $\quad$ o reconhecimento do conceito ampliado de saúde;

- $\quad$ saúde como direito de cidadania, dever do Estado;

- $\quad$ necessidade de controle das políticas sociais pela sociedade;

- $\quad$ constituição de um orçamento social..

PAIM (1997) refere que os princípios constitucionais fundamentaram-se na produção teórico crítica da saúde coletiva em duas direções. Um primeiro eixo, com influência direta das ciências sociais, inscreveu os princípios de:

- $\quad$ direito à saúde;

- cidadania;

- universalidade;

- $\quad$ eqüidade; e

- democracia.

Um segundo eixo, com influência do movimento preventivista, inscreveu:

- $\quad$ regionalização;

- $\quad$ hierarquização;

- $\quad$ atendimento integral;

- participação comunitária; e

- necessidade do desenvolvimento de ações de promoção, prevenção, e recuperação da saúde.

As linhas teóricas da Saúde Coletiva nortearam novas propostas para a organização dos 
serviços de saúde que, em alguns municípios brasileiros se concretizaram em Modelos Alternativos, adequados às realidades locais, com o compromisso de fazer a reforma sanitária.

A partir de 1987, o estado da Bahia, tendo como referência as recomendações da Comissão Nacional de Reforma Sanitária, implantou uma proposta de reorganização do Sistema de Saúde através da implantação de Sistemas Locais de Saúde (SILOS). Os SILOS tinham como eixo diretor a formação de Distritos Sanitários, que funcionariam como unidades operativas. Nestas unidades operativas de base territorial, eram agregados equipamentos de saúde capazes de resolver a promoção, a prevenção e a recuperação da saúde e era garantido aos pacientes a referência para outros níveis de complexidade tecnológica, quando necessitassem.

A organização das práticas de saúde baseava-se na identificação dos problemas locais, tendo como marco de referência saúde/ condições de vida e se consolidava nos territórios. No Distrito Sanitário, articularam-se ,institucionalmente, os recursos públicos e privados para garantir a resolutividade dos problemas, além disso, houve participação popular no acompanhamento em todo o sistema (SILVA JR 1998).

A cidade de Curitiba adotou um Modelo que entendia "saúde como determinação social, mas seus determinantes precisavam ser discutidos" (SILVA JR 1998, p.85). A assistência à saúde, neste modelo, foi organizada em rede com Unidades de Saúde que se responsabilizavam por uma área de abrangência definida e que ofereciam seus serviços organizados por programas. Os médicos das unidades eram generalistas (pediatras, tocoginecologistas, clínico gerais e outros) e recebiam apoio de médicos especialistas de acordo com as necessidades da população. Unidades de urgências regionais, funcionando 24 horas, garantiam o atendimento para as intercorrências. O acesso a exames laboratoriais e a médicos especialistas fora da rede municipal foi assegurado pela articulação entre os serviços públicos e privados. (SILVA JR 1998). 
A partir de 1995, o modelo é denominado Saudecidade, introduzindo uma preocupação do Governo Municipal da época com a problemática da urbanização e geração de agravos, o que aproximou as propostas de Curitiba aos ditames da Carta de Ottawa. Esta carta descreve o resultado da $1^{\text {a }}$ Conferência Internacional sobre Promoção da Saúde, realizada em 1986, ano em que também ocorreu no Brasil a $8^{\text {a }}$ CNS e enumera princípios a serem seguidos pelo mundo para se alcançar Saúde Para Todos no Ano 2000. Resume como principal foco de discussão a promoção da saúde e a intersetorialidade. Entre os compromissos assumidos pelos participantes da conferência, merecem destaque a implantação de políticas saudáveis capazes de ver "a saúde como um recurso para a vida e não como um objetivo de viver" e a preocupação com o meio ambiente natural (BRASIL/ MS 2001).

No enfoque dado à intersetorialidade e às políticas saudáveis, a Carta de Ottawa apontou as bases para a construção de "cidades saudáveis", onde a promoção da saúde estaria garantida. Há dez anos, a cidade de Curitiba possui um planejamento urbano que contribui para a qualidade de vida dos cidadãos (TEMA/RADIS 2000).

A proposta do Laboratório de Planejamento e Administração em Saúde (LAPA), no final da década de oitenta, levou a cidade de Campinas a implantar um modelo tecnoassistencial em saúde denominado "Em Defesa da Vida". O modelo tinha como princípios: Gestão democrática, Saúde como direito de cidadania e serviço público de saúde voltado para a defesa individual e coletiva. $\mathrm{O}$ controle dos prestadores de serviço e da Gestão Municipal foi garantido pela participação popular que tendo acesso às informações institucionais exerceu uma ação efetiva nos rumos da política de saúde.

A concepção de saúde do LAPA era a concepção da epidemiologia social latinoamericana, mas mantinha a valorização da subjetividade no processo de adoecimento, os interesses da demanda dos serviços e a equipe de saúde para que, a partir destes três aspectos, tivesse uma ampla capacidade de perceber a demanda e oferecer serviços adequados. 
A equipe mínima era multiprofissional, com referência para especialistas básicos que incorporavam tecnologias de acordo com as necessidades de resolver os problemas. As diferenças importantes entre o modelo Em Defesa da Vida e os demais estão na valorização da clínica, na organização das unidades de acordo com as demandas locais e na importância dada ao acolhimento dos usuários, entendido como a capacidade da equipe em solidarizar-se com a demanda , criando uma relação humanizada.

Neste modelo, a força do ideal democrático mostrou-se claramente no seu próprio nome. Entre as mudanças iniciadas em 1989, foi destacado por Gastão Wagner de Campos (1991), o clima de debates que agregou muitos profissionais da Secretaria de Campinas.

As formas de organizar um novo modelo adotado por Curitiba (Paraná), Pau da Lima ( Bahia) e Campinas (São Paulo) foram consideradas propostas de modelos da Saúde Coletiva, mas permaneceram como experiências locais, fortalecidas pela presença das instituições de ensino e influenciaram muitas outras experiências inovadoras em municípios brasileiros (SILVA JR 1998). Na organização dos serviços de saúde utilizou-se os conhecimentos da epidemiologia no planejamento das ações, somados à participação popular. Os processos de trabalho para prestação dos serviços foram construídos a partir dos conhecimentos multidisciplinares agregados nas equipes, respeitando-se o saber de cada profissional no desenvolvimento das atividades técnicas.

Outra experiência local de importância, no Brasil, foi a implantação do Programa Médico de Família (PMF), na cidade de Niterói, em 1992, destacando-se como estratégia para construção de um modelo mais adequado à Reforma Sanitária. O modelo tem, na sua ideologia, a concepção cubana do homem como sujeito de sua história e traz a figura do médico como o centro da atenção à saúde levada até as famílias das populações em risco social. A organização do PMF, no Brasil, contou com a assessoria técnica do Ministério de 
Saúde Pública Cubano, através da figura do diretor do policlínico docente de Lawton/Havana, pioneiro no desenvolvimento do modelo daquele país, e ainda recebe influência dos mais diversos programas de atenção básica existentes no mundo (VASCONCELLOS 1998).

Atualmente, o PMF/ Niterói conta com 64 equipes básicas, cada uma composta por um médico e um auxiliar de enfermagem, distribuídas em 18 módulos, atingindo 14\% da população do município, residente em bairros ou aglomerações populacionais de baixa renda e com 3.500 a 4.000 habitantes. Cada equipe é responsável por 250 famílias. Os médicos de família são generalistas responsáveis pela atenção continuada dos indivíduos e das suas famílias. Desenvolvem ações de promoção, prevenção, diagnóstico e tratamento (SENNA e COHEN 2002).

Uma equipe interdisciplinar de especialistas, composta por pediatras, ginecologistasobstetras, clínicos, psiquiatras, assistentes sociais, enfermeiros, psicólogos e sanitaristas dão suporte e supervisão periódica a equipe básica e desenvolve treinamento em serviço e educação continuada para os médicos.

$\mathrm{O} \mathrm{PMF} /$ Niterói foi implantado através de uma estrutura paralela à rede de serviços tradicionais, diferentemente de Cuba, onde a medicina familiar é a porta de entrada do sistema de saúde e há dificuldade em garantir o acesso dos usuários a outros níveis de assistência de maior complexidade tecnológica (SENNA e COHEN 2002). A presença do médico de família é um diferenciador nas experiências locais desenvolvidas na década de noventa e, através do seu trabalho, novas práticas poderiam estar sendo construídas. 
Na segunda metade da mesma década, a política de saúde no Brasil concentrou seus esforços na organização da Atenção Básica e, com o propósito de reorientação do Modelo de Saúde para o SUS, foi recomendado o Programa de Saúde da Família. 


\section{UM NOVO TEMPO}

\subsection{O Programa de Saúde da Família}

A partir de 1993, o MS iniciou a implementação do Programa de Saúde da Família (PSF) no Brasil, considerando, entre outras justificativas, a necessidade de interiorização do SUS. Sobre este aspecto, já havia uma experiência em interiorização para problemas específicos desde 1991, quando o Ministério da Saúde propôs o Programa Nacional de Agentes Comunitários de Saúde (PNACS) com o objetivo central de reduzir a mortalidade infantil e materna. Implantado, inicialmente, na região nordeste e na região norte, vinculado à Fundação Nacional de Saúde (FUNASA), foi inspirado no Programa de Agentes Comunitários de Saúde (PACS), desenvolvido no Ceará, desde 1987, como "frente de trabalho" em uma conjuntura de seca.

A criação do PSF foi inspirada na experiência bem sucedida do programa Médico de Família de Niterói, direcionando-se, primeiramente, ao atendimento da população residente nas áreas delimitadas pelo Instituto de Pesquisa Econômica e Reforma Agrárias (IPEA) incluídas no Mapa da Fome. Posteriormente, outros municípios foram inseridos, principalmente aqueles que faziam parte do Programa Comunidade Solidária ou do Programa de Redução da Mortalidade (MS 2002, p.1).

Apesar de influenciar o governo brasileiro na formulação do programa, não há, entretanto, similaridade estrutural entre o Programa de Saúde da Família brasileiro e o Programa de Médico de Família cubano, bem demonstrada na composição das equipes e no número de famílias sob a responsabilidade de cada médico. 
Na publicação propositiva do MS em 1997, documento chamado "Saúde da Família: uma estratégia para a reorientação do modelo assistencial", ficou estabelecido que a mudança do Modelo de Atenção para o SUS se daria através da substituição da rede básica tradicional pelo PSF, importância esta que foi garantida no Plano de Metas do MS, que elegeu como programas prioritários de governo o PACS e o PSF. No mesmo documento, foram feitas referências às experiências de Distritos Sanitários e Sistemas Locais de Saúde relativas à sua incapacidade na promoção da mudança de modelo, além de ressaltar que o PSF visa a reversão do modelo assistencial, através de "mudança do objeto de atenção, forma de atuação e organização geral dos serviços, reorganizando a prática assistencial em novas bases e critérios" (p.8). Afirma, ainda, que a atenção à saúde está centrada na família, entendida no seu ambiente físico e social, e que o PSF deve ser desenvolvido por uma equipe multidisciplinar, podendo, porém, estar composta minimamente por um médico generalista ou médico de família, um enfermeiro, um auxiliar de enfermagem e de quatro a seis agentes comunitários, com a responsabilidade por 400 a 1000 famílias.

Outras influências podem ser apontadas na formulação do PSF, como referido no relatório de pesquisa de NOVAES “et. al” (1999), destacando-se alguns conceitos da Medicina Comunitária e dos Cuidados Primários em Saúde quanto à ação nas comunidades e outros trazidos dos Movimentos Populares como a importância da participação popular, o que no Brasil já estava garantido por lei desde 1990.

Na publicação que serviu de guia para a implantação do PSF no ano de 1994 (MS. FUNDAÇÃO NACIONAL DE SAÚDE, PSF 1994, p.7), a ênfase à mudança do modelo estava descrita nas "Bases do Programa", tendo sido explicitado que a mudança consistia em afastar-se do atual modelo assistencial centrado na doença e no hospital, enfatizando a promoção e prevenção. 
A Portaria $\mathrm{n}^{\circ}$ 1886/GM MS/, 18 de out de 1997, que estabeleceu Normas e Diretrizes para o PACs e o PSF traz, no Anexo 2, as diretrizes operacionais do programa, nomeando como "aspectos que caracterizam a reorganização das práticas de trabalho":

- $\quad$ caráter substitutivo das práticas tradicionais;

- $\quad$ integralidade da assistência;

- $\quad$ programação e planejamento descentralizados; e

- territorialização / adscrição de população

O programa, também considerado uma estratégia, deslocou as possibilidades de mudança do modelo tecnoassistencial com enfoque sistêmico para uma mudança focalizada em parte do sistema que é a rede básica. Categorizou um novo ator na área de saúde, o agente comunitário, reorientou a enfermagem em seu antigo campo de atuação e nomeou competências para os médicos, que se colocam para além do "núcleo de saber" adquirido na sua formação, conforme definição adotada por CAMPOS (2002). A exigência de novos saberes faz-se necessária para a interação dos profissionais com os pacientes, suas famílias e seu território, para entender as dimensões sociais do adoecimento, na leitura da antropologia, da psicologia, da economia, para além da clínica e da epidemiologia, nitidamente recomposta nas ações de Vigilância em Saúde.

A forma de financiamento para as atividades do programa, em 1993, foi garantida, primeiramente, como custeio, valendo um salário mínimo por agente. Com a Portaria Ministerial no 692 de 25 de março de 1994, ficou estabelecida uma forma complementar de financiamento em que os procedimentos realizados pelo programa e cadastrados no Sistema de Informações Ambulatoriais do SUS (SIA/SUS) passaram a ser pagos de acordo com Tabela SIA/SUS, valendo o dobro do valor das consultas médicas tradicionais. Este tipo de financiamento por faturamento não foi considerado o mais adequado por não valorizar as atividades de promoção e prevenção da saúde, entretanto, estimulou a implantação do PSF nos municípios, porque as consultas do programa valiam muito mais que consultas tradicionais. 
A NOB/96, que tratou das formas de gestão municipa,l caracterizou o primeiro nível da assistência à saúde como atenção básica e garantiu recursos financeiros federais repassados aos municípios num valor per capita denominado Piso de Atenção Básica (PAB). Este financiamento deveria dar suporte ao desenvolvimento da atenção à saúde das populações no limite das responsabilidades municipais.

A Portaria do MS n 1882/97 que estabeleceu o PAB criou um incentivo especial adicional ao PAB (PAB Variável) para os municípios que desenvolvessem alguns programas prioritários e, entre os contemplados, o PSF. O incentivo financeiro do Governo Federal contribuiu decisivamente para a rápida expansão do programa a nível nacional. Em outubro de 1998, já havia 1219 municípios com equipes de saúde da família, com os mais variados graus de cobertura populacional, o que negava a possibilidade de um modelo substitutivo do modelo tradicional. Posteriormente, foi estabelecido um novo incentivo financeiro.

Uma das características importantes na construção do sistema de saúde brasileiro está na racionalidade necessária para a universalização do acesso da população à assistência e, para que seja resolutivo, deve garantir o acesso a tecnologias médicas. O sistema pressupõe uma rede de serviços com tecnologias diferenciadas, em que o cidadão percorre, referenciado, o nível secundário e o nível terciário, de acordo com princípios do SUS, tão bem discutidos por muitos autores. A resolubilidade não é garantida no PSF e a integralidade que se concretiza, dependente da Gestão do Sistema de Saúde até as práticas profissionais específicas, tem sido pouco efetiva no sistema de saúde brasileiro e segundo GIOVANELLA et al (2002) no estudo sobre critérios para avaliar a integralidade, este conceito foi pouco trabalhado enquanto orientador de mudanças de modelo assistencial que reproduz a agregação de ações preventivas individuais ao atendimento clínico, vinculado aos programas de atenção básica. 
Deve-se ressaltar que em nenhum modelo a ser adotado para a área de saúde será aceita a priorização de ações de prevenção em detrimento da organização do acesso às ações assistenciais curativas a todos os cidadãos, como refere a Constituição Brasileira.

Parece que, onde não havia nenhuma forma de assistência à saúde, o PSF foi benéfico, levando atenção médica e de enfermagem às localidades afastadas das sedes dos municípios, áreas rurais e áreas de periferia urbana como, por exemplo, o Estado do Espírito Santo e principalmente nos pequenos municípios, com menos de 20000 habitantes, onde a cobertura de $100 \%$ da população se dá com apenas 3 equipes. Esta forma de implantação aproximou o PSF ao princípio da eqüidade, pela vertente do acesso às ações de saúde. Mas, vale considerar a reflexão sobre eqüidade em SENNA (2002), onde a autora reforça a necessidade de que as ações focais se integrem a uma política de suporte social para garantia dos direitos universais e que é preocupante a interferência política clientelista nos critérios de escolha das áreas para implantação do PSF.

Sendo o PSF uma estratégia para a mudança do modelo, a partir da reorganização da Atenção Básica, foi necessária a definição precisa de que nível de atenção se referia o programa, tendo em vista o que vinha sendo tratado sob as denominações de primário, secundário e terciário na interpretação da hierarquização dos serviços de saúde e o que seria de responsabilidade dos profissionais do PSF. As ações de saúde, incluídas nesta modalidade de atenção foram definidas, pela primeira vez, na publicação do MS/98, Manual de Organização da Atenção Básica, aprovado pela Portaria GM/MS nº 3925, de 13 de novembro de 1998, que definiu: "Atenção Básica é um conjunto de ações de caráter individual e coletivo, situadas no primeiro nível de atenção no sistema de saúde, voltadas para promoção a saúde, prevenção de agravos, tratamento e reabilitação".

O difícil é construir um novo modelo para consolidação do SUS, tendo, na base, um paradigma que admite inúmeros fatores envolvidos no processo saúde-doença, com uma 
equipe mínima, cuja capacidade de intervenção nas necessidades de saúde concentra-se apenas num dos fatores, ou seja, as ações dos serviços de saúde.

Admitir as diferenças é permitir estratégias alternativas, não únicas para todas as cidades e nem para todos os territórios de uma grande cidade, que são dependentes da complexidade das necessidades locais e que podem desencadear mudanças que prescindam da substituição da rede, mas que possibilitem a complementação da rede de assistência para o cumprimento das orientações constitucionais.

\subsection{A História das Mudanças no Município de Vitória}

Em 1990, o governo do Estado do Espírito Santo e o Governo Municipal de Vitória posicionaram-se à frente de muitos governos, com relação à construção da legalidade local que amparasse a construção de novo Modelo de Atenção à Saúde. Em 4 de janeiro de 1990, o governo do Estado do Espírito Santo publicou, no Diário Oficial, a Lei 4317 - Modelo Assistencial para o Estado do Espírito Santo que, juntamente com a Lei Orgânica do Município de Vitória, incorporaram a integralidade da atenção à saúde e buscaram ordenar níveis hierárquicos de assistência. A presença da participação popular foi fator determinante para a orientação dos papéis de cada governo.

A categorização das Unidades de Saúde de Vitória obedeceu às características delimitadas pelo documento estadual: Proposta de Reorganização no Setor Saúde/ES, elaborado por GT/SESA/IESP, dezembro de 1988 a junho de 1989, que, depois, foi ratificado pela LEI 4317. 
O Modelo então estabelecido nos documentos caracterizava os serviços de saúde dispostos em níveis hierárquicos de complexidade:

Nível 1 - Unidades Básicas de Saúde da rede ambulatorial: US1, US2, US3,

Nível 2 - Centros Regionais de Especialidades, Hospitais Regionais e rede complementar.

Nível 3 - Hospitais Especializados e de Especialidades

Até 1992, só o Nível 1 ficou sob a responsabilidade municipal, mas a Lei Estadual garantia os fluxos de atendimento para referências aos demais níveis de complexidade. A Secretaria Municipal de Saúde organizou seu sistema de saúde, classificando as Unidades de Saúde em: Unidade de Saúde 2, Unidade de Saúde 3A e Unidade de Saúde 3B. Os Médicos e odontólogos estariam presentes nos três níveis de organização, mas na US 3B também estariam lotados médicos especialistas, de acordo com o perfil epidemiológico da região. Nas três categorias hierárquicas, os serviços de diagnóstico e insumos terapêuticos eram garantidos, mas somente as US3B possuíam laboratório e serviço de Raio-X próprios.

O Plano Municipal de Saúde da Gestão 1988-1992, além de caracterizar o município que, pela primeira vez, tinha um sentido de organização na área de saúde, dividia-o em 14 Regiões de Saúde, tendo sido considerados, para determinação dos seus limites, os aspectos geográficos, o acesso viário, a distribuição populacional e de equipamentos de saúde.

Em 22 de agosto de 1989, o município de Vitória assinou o convênio de municipalização da Vigilância Epidemiológica e Sanitária de Alimentos, com o objetivo primordial de avançar na municipalização de atividades que complementariam as propostas municipais de construir um sistema baseado na promoção, prevenção e recuperação da saúde.

Nos primeiros anos do governo, a estrutura da assistência básica municipal já demonstrava sinais de melhoria na intenção do cumprimento das metas estabelecidas de 3,13 
cons/hab/ano para consultas médicas e 1,0 cons/hab/ano para consultas odontológicas (PMV/ SEMUS, 1991). Durante o ano de 1991, quatro grupos de profissionais, lotados nas Unidades de maior complexidade, iniciaram a descentralização das vigilâncias, respondendo por estas ações nos antigos moldes dos programas e delimitando suas áreas de abrangência de acordo com o que já estava estabelecido no modelo de organização médico-sanitária. Foram sedes das equipes: Centro de Saúde de Maruípe, Centro de Saúde de Santo Antônio, Centro de Saúde de Vitória e Pronto Atendimento Médico Goiabeiras (PAM Goiabeiras) que, apesar de um serviço de saúde sob a gerência federal, criou um Núcleo de Vigilância na complementação do sistema municipal. Este núcleo federal, composto por uma sanitarista e uma assistente social, iniciou um projeto para criação de Áreas de Vigilância, Área I de Goiabeiras, com a oficialização e sistematização das atividades que deveriam ser desenvolvidas por Goiabeiras e demais áreas. Após a inauguração da unidade municipal - US3B Jardim Camburi - foi criada a quinta Área de Vigilância - Área V de Jardim Camburi. Estas áreas não correspondiam às 14 Regiões de Saúde do Plano Municipal de Saúde e não correspondiam às áreas administrativas das demais secretarias municipais, mas era a possibilidade de se iniciar a regionalização, conforme organização do trabalho das visitadoras sanitárias que tinham como referência a delimitação por bairros.

Com o propósito de capacitar o Município para assumir progressivamente as responsabilidades da municipalização, o governo implementou estratégias, como: o concurso público para diversas categorias profissionais e o Curso descentralizado de Saúde Pública, ministrado pela Escola Nacional de Saúde Pública (1992). Em 1994, todos os núcleos de descentralização haviam sido capacitados, em áreas específicas de Vigilância Sanitária, Investigação Epidemiológica e já tinham experiência em projetos especiais sobre o controle de riscos de produtos e serviços de interesse para a saúde onde a prioridade foi a educação sanitária de proprietários, manipuladores e consumidores. O sistema de informação de doenças transmissíveis mantinha regularidade nas notificações de fontes formais (serviços de saúde) e informais (escolas, creches e etc), com o trabalho de rotina de visitas de fontes notificadoras e publicação de consolidados de dados coordenados pelas sanitaristas. O aprimoramento do 
sistema se deu a partir da implantação das Unidades de Vigilância Epidemiológica Intra Hospitalar.

Neste mesmo ano, o treinamento dos profissionais, lotados no nível central municipal e no nível local em Metodologia de Estimativa Rápida, possibilitou um novo caminho para o Diagnóstico Local de Saúde, com efetiva participação das comunidades. O método foi um facilitador da mobilização da população, agregou diferentes ideologias na construção das equipes e nas oficinas de treinamento; no entanto, já era claro o desinteresse dos profissionais médicos das Unidades de Saúde neste processo.

Durante as fases preparatórias para o desenvolvimento dos diagnósticos, as reuniões com as comunidades favoreceram o reconhecimento do Núcleo de Vigilância em Saúde como autoridade sanitária local.

As Áreas de Vigilância em Saúde estavam assim distribuídas:

I - Goiabeiras

II - Maruípe

III - Centro

IV - Santo Antônio

V - Jardim Camburi

VI - São Pedro

VII - Forte São João.

Os diagnósticos locais de saúde foram desenvolvidos durante o ano de 1995, coordenados pelas equipes dos Núcleos de Vigilância em Saúde, que estabeleceram a dinâmica para a mobilização das comunidades e agregaram ao processo profissionais de outras instituições, principalmente da Universidade Federal do Espírito Santo. Até setembro de1996, todos os diagnósticos locais de saúde já haviam sido apresentados às comunidades, 
enfatizando as características peculiares dos bairros. Na etapa seguinte, que envolvia o planejamento das ações de saúde e exigiam mudanças na organização das unidades, as resistências foram claras. Para minimizar os conflitos e difundir os novos conceitos, foram organizadas oficinas de sensibilização em todos os serviços de saúde, com a participação de todos os profissionais, na busca da construção de um novo modelo de saúde para Vitória.

O modelo tecnoassistencial em saúde para Vitória, na forma de SILOS, estabeleceu como princípios organizativos:

- $\quad$ participação popular;

- $\quad$ descentralização;

- $\quad$ democratização;

- $\quad$ territorialização;

- $\quad$ intersetorialidade; e

- $\quad$ a prática da vigilância em saúde.

Com a consultoria da Professora Dra. Carmen Vieira de Sousa Unglert, as Áreas de Vigilância em Saúde foram territorializadas, gerando grande expectativa na mudança de condutas dos profissionais das Unidades de Saúde, com apropriação dos territórios* . Os problemas estavam descortinados, os territórios delimitados, mas o planejamento, a partir das necessidades, não se concretizou em todo o município. Na Área VII São Pedro, foi implantado o programa escolhido como prioridade local, Saúde da Criança, que garantia o cadastramento e acompanhamento de toda criança daquela área durante o seu primeiro ano de vida. As crianças, localizadas por busca ativa, a partir da Declaração de Nascido Vivo (DN), recebiam a Caderneta da Criança para registro de todos os acontecimentos. Apesar de bem aceito pelos pediatras da Área de São Pedro, o programa não se consolidou em toda a rede de assistência do município, onde a gerência das unidades impossibilitava o avanço na construção do novo.

\footnotetext{
* De 1993 a 1996 estive na chefia da Divisão de Vigilância em Saúde que coordenou o processo no município.
} 
Em dezembro de 1996, o Município de Vitória estava dividido em 7 Áreas de Vigilância em Saúde e 22 territórios, com as equipes de sanitaristas e agentes de saúde pública $^{* *}$ regionais, tendo cada Unidade de Saúde responsabilidade sanitária sobre sua área de abrangência e já se constituindo os primeiros Conselhos Locais de Saúde, sob a indicação da II Conferência Municipal de Saúde de 1996, que teve como tema: "Sistemas Locais de Saúde: construindo a saúde que queremos".

As equipes de Vigilância em Saúde permaneceram no Nível Local até o primeiro trimestre de 1997. Após esta data, os sanitaristas e os agentes de saúde pública foram remanejados para o Nível Central, formalizando a centralização da Vigilância em Saúde. Este fato caracterizou um retrocesso na construção do modelo baseado nas propostas de descentralização e construção dos SILOS. Apesar da clareza como esta diretriz é colocada no Plano Municipal de Saúde de 1997 não existe registro documental que justifique a mudança de rumos e o desaparecimento da Divisão de Vigilância em Saúde. Importante ressaltar que não existe, no Relatório de Gestão do ano de 1997, a justificativa da centralização (PMV/SEMUS, 1997).

As atividades de assistência, permaneceram ligadas aos programas específicos organizando a demanda através do Programa de Atenção Integral à Saúde da Criança (PAISC), Programa de Atenção Integral à Saúde da Mulher (PAISM), Sorria Vitória, Programa de Hipertensão, Programa de Diabetes e Atenção ao Idoso, mas era nítida a impossibilidade de mudar a lógica de trabalho dentro das Unidades de Saúde onde o modelo médico assistencialista gerava produtividade.

Uma grande mobilização da população e dos profissionais foi desencadeada nas Regiões, principalmente na Região de São Pedro, para discutir os novos rumos que 
possibilitassem a apropriação dos territórios. Uma nova onda de mudança estabeleceu-se no município, apoiada pela população, sob a influência da intensa propaganda do MS. O discurso inovador do PSF, direcionado sobretudo à melhoria dos serviços pela mudança da estrutura das unidades que, agora, seriam da saúde da família, tornou-se uma opção, já que os processos de trabalho dentro das unidades convencionais não se direcionavam para as áreas de abrangência determinadas pela territorialização e permaneciam na lógica de prestação de serviços priorizados pela gerência da unidade local sob a pressão da demanda espontânea.

\subsection{Saúde da Família - Estratégia para o Novo Milênio}

Com o projeto: "SAÚDE DA FAMÍLIA - UMA ESTRATÉGIA PARA O NOVO MILÊNIO” (SEMUS 1999), implanta-se o programa o PSF no município de Vitória. No processo de aprimoramento da descentralização, trazido pela NOB 96, o município de Vitória habilitou-se na Gestão Plena da Atenção Básica, gerenciada pela Secretaria Municipal de Saúde de Vitória (SEMUS), responsabilizando-se pelo atendimento a uma população de 299.358 habitantes (SEMUS 2002). Sua estrutura administrativa, criada pela Lei nº 3983/93, é composta por três departamentos - Departamento de Administração em Saúde, Departamento de Ações integrais de Saúde e Departamento de Avaliação e Controle; o Fundo Municipal de Saúde; 3 núcleos de trabalho - Núcleo de Planejamento, Núcleo de Recursos Humanos e Núcleo de Processamento de Dados; e uma Unidade de Apoio Setorial que, atualmente, necessita de reestruturação para atender a complexidade exigida pela municipalização. Para gerenciamento exclusivo da assistência, foi criado o Departamento de Assistência à Saúde, ainda informal, com gerências específicas para cada programa, onde o PSF está incluído.

O município está atualmente dividido em 6 Regiões de Saúde, 25 territórios e possui uma rede física composta de 26 Unidades de Saúde, 14 Unidades de PSF, 2 Pronto Atendimentos, 1 Policlínica de Especialidades, 6 Centros de Referência, 8 Módulos de Orientação ao Exercício e 1 Laboratório Municipal (Anexo I).

\footnotetext{
** Categoria de profissionais de nível médio, efetivos, concursados em 1992, com competência de atuação na área de vigilância sanitária e epidemiológica.
} 
A oferta de serviços de saúde está condicionada ao tipo de gestão e orientada de acordo com os parâmetros e normas publicadas pelo MS para a atenção básica e pela publicação municipal: Manual para a Atenção Básica no Município de Vitória (2000), direciona no âmbito do município e nos territórios o atendimento programático das Unidades Básicas, de acordo com políticas específicas de: vigilância sanitária e epidemiológica, saúde da criança, saúde da mulher, saúde do adolescente, saúde do idoso, controle das doenças crônico-degenerativas, saúde mental, prevenção e tratamento das DST/AIDS e saúde do trabalhador.

Em 13 de setembro de 2002, atendendo à recomendação da Secretaria de Políticas do Ministério da Saúde, o município de Vitória encaminhou Termo de Adesão à Gestão Plena da Atenção Básica Ampliada à Secretaria Estadual de Saúde e ao Ministério da Saúde, o que aumentou o elenco de procedimentos da atenção básica sob sua responsabilidade.

A iniciativa de implantação do Programa de Saúde da Família no município de Vitória surge do pressuposto da garantia de acesso aos serviços, com base na promoção da saúde, na resolutividade das ações e no fortalecimento do vínculo com a comunidade, mas, com a centralização das equipes de vigilância em saúde, a estratégia amparou-se na assistência. Em 1997, foram selecionadas as áreas para implantação do programa:

- $\quad$ Resistência (Área VI);

- $\quad$ Morro do Moscoso, Piedade e Fonte Grande (Área III);

- $\quad$ Andorinhas (Área II);

- $\quad$ Jesus de Nazaré (Área VII)

Em 1998, as primeiras equipes selecionadas foram compostas por médico, enfermeiro, auxiliar de enfermagem e pelos agentes comunitários de saúde. Para a implantação, os 
profissionais de nível superior da rede municipal de assistência receberam treinamento específico por meio da Assessoria do Canadá em convênio com a Secretaria Municipal de Saúde. As comunidades que receberam o Programa foram selecionadas pelo índice de pobreza, pelos indicadores de saúde desfavoráveis e pela simultaneidade com o atendimento do Projeto Terra ${ }^{*}$. As equipes foram instaladas em Unidades de Saúde tradicionais, com a intenção de tornarem-se facilitadoras na apropriação dos territórios anteriormente delimitados. Este fato está documentado no projeto Saúde da Família - Estratégia para o Novo Milênio (SEMUS 1999), segundo cronologia apresentada na Tabela I.

Tabela I - Cronologia da implantação do programa de saúde da família, Vitória/ES, anos 1998-2002.

\begin{tabular}{|c|c|c|}
\hline Unidades de Saúde & $\mathrm{N}^{\mathrm{o}}$ de equipes PSF & Início das atividades \\
\hline U.S. Bairro da Penha & 5 & $\mathrm{Mar} / 2000$ \\
\hline U.S. Jardim da Penha & 5 & Jun/2000 \\
\hline U.S. Ilha do Príncipe & 1 & Out/1998 \\
\hline U.S. Fonte Grande & 1 & Ago/1998 \\
\hline U.S. Resistência & 2 & Fev/1998 \\
\hline U.S. São Pedro V & 3 & Fev/2000 \\
\hline U.S. Santo André & 3 & Fev/2000 \\
\hline U.S. Ilha das Caieiras & 3 & Fev/2000 \\
\hline U.S. Jesus de Nazaré & 2 & Fev/1998 \\
\hline U.S. Andorinhas & 4 & Ago/1998-set/200 \\
\hline U.S.Consolação & 6 & Set/2000 \\
\hline U.S.M.Comunitária & 2 & Mai/2001 \\
\hline U.S. Maruípe & 5 & Set/2001 \\
\hline
\end{tabular}

Fonte: Departamento de Assistência à Saúde da Saúde da Secretaria Municipal de Saúde de Vitória, Vitória, Julho 2002

\footnotetext{
* Projeto do Governo Municipal para urbanização de morros e palafitas da cidade com ações intersetoriais para melhoria da qualidade de vida destas populações.
} 
No ano 2000, inicia-se, na Região de São Pedro, como projeto piloto e sob a assessoria da OPS, o Projeto Integrar - Projeto de Implantação do Sistema Integrado de Serviços de Saúde (SISS) - que tem como meta "a construção de uma rede de serviços integrados para garantia de um atendimento de qualidade e humanizado para a assistência aos munícipes" (SEMUS 2002), com perspectiva de ampliação para toda a cidade até o ano 2004. Este Projeto surgiu da reivindicação dos profissionais para a garantia da resolutividade do nível local e foi precedido de "um processo educativo que é de intervenção" (p. 16) onde foram realizados 15 seminários temáticos,, em um período de 11 (onze) meses com o envolvimento de, aproximadamente, 1600 (um mil e seiscentos) participantes.

O Projeto Integrar, composto de 11 sub-projetos para o desenvolvimento de áreas específicas, reafirma o Programa de Saúde da Família (PSF), como eixo organizador da Atenção Primária à Saúde (APS), que é a base do SISS. Dois sub-projetos, diretamente relacionados à construção do Modelo de Atenção à Saúde, enumeraram, em seus objetivos específicos, aspectos da organização do sistema de saúde. No primeiro sub-projeto, a Organização da Atenção Básica, os objetivos específicos de criar mecanismo de integração entre as equipes do PSF e a comunidade e definir as competências dos recursos humanos na Unidade de Saúde da Família já deviam ter sido superados porque estão relacionados a aspectos fundamentais no desenvolvimento e operacionalização do programa.

No segundo sub-projeto, Descentralização da Vigilância Epidemiológica, Ambiental e Sanitária, o objetivo específico de organizar, de forma descentralizada e integrada, o Sistema de Vigilância Epidemiológica, Ambiental e Sanitária é o resgate de uma experiência interrompida no ano de 1998. A opção do PSF, em Vitória, de não assumir as atividades relacionadas ao controle de agravos transmissíveis tem trazido sérios problemas no controle das doenças de notificação compulsória no nível municipal. 
$\mathrm{Na}$ estruturação da assistência, a primeira referência do SISS é o médico generalista, apoiado pela equipe de médicos do Programa de Educação Permanente (PEP), que estão organizados como Grupos de Apoio Permanente (GAP), um para cada região de saúde, que os assessoram nas dificuldades clínicas. Na proposta para a Região de Saúde São Pedro, as referências para outros níveis de complexidade tecnológica são garantidas na Policlínica de São Pedro. Nas demais regiões de saúde, estão sendo mantidas as referências do Sistema Estadual.

A Secretaria Municipal de Saúde fez um grande investimento financeiro na estratégia do PSF, que já cobria $44 \%$ da população do Município no ano 2002. Necessitou redirecionar os profissionais médicos das práticas tradicionais - pediatria, ginecologia e clínica - para outras atividades no nível central e serviços ambulatoriais por não aderirem ao programa. Os enfermeiros que estavam nas Unidades de Saúde (US), principalmente em cargos de gerência, optaram por fazer parte das equipes, e os agentes comunitários de saúde foram contratados conforme orientação do Ministério da Saúde.

Durante os últimos cinco anos, pela observação dos fatos ocorridos no Estado do Espírito Santo, ficou demonstrado que a defesa do PSF não refletia o verdadeiro entendimento da complexidade da organização de serviços. Muitos fóruns e seminários organizados pelas Secretarias Estadual e Municipal de Saúde, pareciam esperançosos em resolverem todos os problemas dos serviços de saúde com a implantação do PSF, acreditando que o agente comunitário seria capaz de identificar crianças, gestantes, doentes mentais, portadores de tuberculose, suspeitos de hanseníase, acompanhar os acamados e tantas outras tarefas, esquecendo-se de que ele deveria ser apenas a voz do território. Representou ampliação de mercado de trabalho para alguns profissionais, alteração do sistema de remuneração para todos e o tempo integral da equipe seria a chance da criação de vínculo com as comunidades. 
Existem muitas perguntas sem respostas, como: o que fazer com a demanda espontânea? Sendo a principal característica da assistência no modelo médico privatista ainda não corretamente direcionada dentro do município de Vitória, permanece como a causa de problemas nas unidades de saúde. Este fato está documentado no relatório de conclusão das reuniões sobre a estruturação da demanda do PSF, realizadas durante o ano 2002 (SEMUS/PEP 2002), e apontou como problemas importantes:

- $\quad$ pressão das gerencias das unidades de saúde para atendimento dos pacientes;

- $\quad$ ausência de triagem antes da consulta médica;

- $\quad$ falta de definição do papel de cada categoria profissional, incluindo limites de ação e responsabilidade ético-legal;

- distanciamento da mudança de modelo por não realizarem adequadamente os programas preventivos; e

- $\quad$ presença da comunidade interferindo no trabalho das equipes e gerando conflitos.

No dia-a-dia de nossos serviços, a forma como as Unidades de Saúde da Família (USF) organizam suas atividades e as equipes distribuem as ações de promoção, prevenção, e recuperação da saúde está subordinada à mesma lógica de programas, compatível com o perfil dos profissionais que as executam. As atribuições de cada profissional estão normalizadas nas publicações do Ministério da Saúde e uma coordenação municipal gerencia a implementação do programa no município. Já estão sendo elaborados protocolos clínicos para o atendimento de grupos prioritários, o que facilitará a padronização do atendimento médico aos munícipes, sejam em unidades do PSF ou unidades tradicionais.

Avaliar o Programa de Saúde da Família como uma estratégia para mudança do modelo assistencial, e não apenas como forma de reorganizar a atenção básica, torna-se imprescindível no momento da consolidação do programa nos municípios brasileiros. Para o município de Vitória, sendo uma estratégia apontada no relatório final do planejamento 
estratégico Vitória do Futuro ("Vitória 2015”), é o momento de possíveis correções para que o Modelo de Saúde do município se consolide.

CONTANDRIOPOULOS (1997) refere que "avaliar consiste fundamentalmente em fazer um julgamento de valor a respeito de uma intervenção ou sobre qualquer um dos seus componentes, com o objetivo de ajudar na tomada de decisão" (p.31). Geralmente, avaliamos as intervenções em saúde através dos resultados alcançados, e, estes resultados, sob a forma de indicadores que podem ser comparados.

HARTZ (2000), ao considerar a necessidade de avaliação do PSF, focalizando a reorientação da atenção básica para um modelo assistencial coerente com princípios do SUS, considera que os indicadores de morbimortalidade não são capazes de apreender as mudanças desejáveis no que se referem aos componentes inovadores do modelo de saúde, apesar de serem os mais utilizados para demonstrar o impacto positivo da estratégia na organização da atenção básica. Esta forma de avaliar deixa de fora da análise os componentes teóricos essenciais para a construção do novo modelo que vá ao encontro dos princípios do Sistema Único de Saúde.

MERHY (2002), ao analisar o PSF como prioridade do Governo Federal, afirma que é preciso "verificar as fragilidades do programa tal como tem sido proposto e fazer um esforço para que sirva como um dispositivo a mais, de mudança de modelo assistencial" (p.121). Com este comentário, o autor chama atenção para o modo como o PSF está sendo avaliado em alguns momentos, desconsiderando a abordagem das necessidades de saúde e as práticas de saúde complexas.

Considera-se que a implantação do PSF existe no município de Vitória quando estão observadas as estruturas organizacionais que caracterizam o programa: territórios delimitados, médicos generalistas, agentes comunitários de saúde e equipes mínimas, com responsabilidade 
por um determinado número de famílias, e têm como lócus da assistência básica a Unidade de Saúde da Família. Para analisar o programa como uma intervenção no espaço geográfico delimitado, o território, admite-se que o PSF está em 14 unidades, com cobertura de 25 territórios, não sendo objeto de análise a implantação, mas a intervenção adotada para mudar uma situação. (SEMUS/ PEP/2003).

Partindo-se do conceito de que uma intervenção é constituída pelo conjunto de meios (físicos, humanos, financeiros, simbólicos), organizados em um contexto específico, em um dado momento, para modificar uma situação (CONTANDRIOPOULOS 1999, p.21) e adotando-se o referencial de HARTZ (1997), que refere a importância dos atores nas etapas de uma intervenção, e que estes atores, tendo objetivos específicos, podem ser avaliados separadamente, o PSF poderá ser avaliado através do meio humano, representado pelo médico do PSF. O momento escolhido é o ano de 2003, na Região de São Pedro, onde a estratégia está implantada há mais de quatro anos, com cobertura de $100 \%$ da população.

\subsection{O Médico do PSF}

As competências médicas no PSF reeditam uma nova proposta de mudança, com mudança da prática médica sobre o adoecer individual e coletivo, no contato com a população, na identificação dos problemas, na formulação de um diagnóstico e posterior encaminhamento das soluções. São os trabalhadores do PSF que vão operar a mudança de modelo e, para que a mudança da prática dos médicos seja reconhecida, é necessário relacionar atributos que a qualifiquem como nova, identificando, assim, a eficácia de sua contribuição na resolução de problemas das populações na dimensão da multicausalidade e da determinação social.

Na Estrutura do Programa de Saúde da Família, o profissional médico é reafirmado como núcleo da atenção à saúde, caracterizando a sua presença ou não a viabilidade do 
programa. Com Médico, é PSF; sem Médico, é PACS. A remuneração muito diferenciada de quaisquer outros profissionais das equipes pode levar ao entendimento do grau de importância que é dada à prática médica. A demanda espontânea por atendimento às intercorrências clínicas ainda é grande nas unidades, exigindo ações efetivas de assistência médica individual. Esta prática é reivindicada em muitas comunidades, por vezes representadas nos Conselhos Locais de Saúde, como necessidade de aumento da oferta de consultas médicas (SEMUS/DAC 2003). A interdisciplinaridade é difícil de concretizar-se em equipes mínimas e a intersetorialidade, buscada desde a década de 80 no desenho dos projetos de assistência integral, ainda é informal no PSF.

O médico do PSF, um novo profissional entre os profissionais médicos, que incorpora, na sua prática, novas técnicas de atuação no território, deverá diferenciar-se dos demais médicos, através de um conjunto de práticas, desenvolvidas no PSF, manifestando seu domínio no emprego de novas tecnologias, a serem reconhecidas, não no sentido técnico científico restrito, mas no sentido amplo das relações sociais.

SCHRAIBER (1993, 1995 e 1996), ao discutir a profissão médica, caracteriza como base do trabalho médico a técnica e a ética, localizando a ética no aspecto relacional do trabalho, e a técnica, como responsável pela externalidade da profissão. Quanto ao processo de trabalho, há a abordagem deste como um processo de intervenção que articula a natureza tecno-científica com o pragmatismo e, por isso, é necessária a construção de éticas de comportamento sobre o adoecer, bem caracterizado quando o médico faz as melhores escolhas técnicas e escolhas terapêuticas a serem seguidas para que o doente tenha um "bom viver". Estas éticas vão permitir a relação entre dois indivíduos num encontro privado, a consulta, numa relação de dependência onde o médico julga as necessidades do doente a partir da transformação do sofrimento singular em anormalidade objetiva das estruturas corporais (doença), com possibilidade de ações reparadoras. Todo o processo acontece com consentimento do doente porque o médico tem autoridade, caracterizando assim uma subordinação moral. 
A autora refere que a maior transformação ocorrida na prática médica deu-se a partir da incorporação tecnológica, o que gerou dependência entre outras formas de trabalho para complementação do trabalho médico, surgindo, daí, a necessidade da divisão hierarquizada dos papéis nas equipes.

A prática médica tem um duplo aspecto, de ser tecno-científica e tecno-arte, com verdades apoiadas pela ciência, que a torna legítima na sociedade contemporânea, e arte, quando a ação criativa, envolvendo a subjetividade, traduz-se na escolha, na forma e na abrangência da ação transformadora (SCHRAIBER 1995). O trabalho médico exige normas de condutas que se constroem a partir da técnica e se inscrevem nas características pessoais do agente, sendo, portanto, consideradas arte quando estas características pessoais conduzem a um procedimento técnico eticamente adequado. É no médico que se consolida o trabalho médico (atenção médica). Ele é núcleo autônomo do modelo de saúde ainda estabelecido no país, que excluiu os componentes coletivos da doença e onde toda o socialidade da saúde, isto é, todo o processo de determinação das carências e das necessidades, influenciadas pelos valores do grupo social ao qual o indivíduo pertence, transforma-se em patologias.

Os médicos foram mudando a cada época, a cada novo conhecimento ou novos equipamentos e, principalmente, no processo de mudanças sociais muito bem marcadas na história brasileira. Ao se afastar o médico do paciente, seja pela mecanização exagerada dos diagnósticos, pelas regras de organização dos serviços ou pela perda do carisma médico, a arte médica torna-se enfraquecida na relação médico-paciente. A arte médica estaria na capacidade de ouvir, confortar, orientar e outras características subjetivas do agente que se transformam em tecnologia para operar uma intervenção. (SCHRAIBER 1996).

Sob esta lógica, espera-se que, no trabalho médico (onde a complexidade das operações estão na capacidade do sujeito), a técnica esteja apoiada no conhecimento científico, atualizado para identificação e resolução dos problemas, e que a arte seja capaz de identificar, 
agir, relacionar os múltiplos fatores de determinação do processo saúde-doença, sob valores éticos universais que conduzam relações interpessoais, na perspectiva da humanização e vínculo, num mundo de muitas morais, trazidas dos territórios onde se deve reconhecer o sujeito com direitos de cidadania, em busca de uma ação transformadora, mas solidária.

A possibilidade de mudança do Modelo de Atenção à Saúde, através da implantação do PSF, já está delineada, a partir da equipe e das atribuições que estão estabelecidas para cada profissional. No desempenho das atribuições, consolida-se a mudança das práticas de saúde e, a partir destas, o caráter substitutivo do modelo. As atribuições desenham o cenário futuro, possível.

No documento, publicado pelo Ministério da Saúde, em 1997, "Saúde da Família, uma estratégia para reorientação da Atenção Básica", as atribuições médicas estão enumeradas de forma abrangente, o que se modifica na publicação, "Cadernos de Atenção Básica, Programa de Saúde da Família-nº 1" (MS 2000), oportunizando, desta forma, a permanência da prática médica restrita às seguintes atribuições:

- $\quad$ executar ações de assistência integral, aliando a atuação clínica à de saúde coletiva;

- $\quad$ assistir as pessoas em todas as fases e especificidades da vida: criança, adolescente, mulher grávida, adulto, trabalhador, portador de deficiência específicas e idosos;

- $\quad$ realizar atendimentos de primeiros cuidados nas urgências;

- realizar pequenas cirurgias ambulatoriais; $\mathrm{e}$

- $\quad$ realizar partos, se suas condições locais o permitem.

Na caracterização do profissional médico mais adequado para o PSF, o documento de 1997 nomeia a preferência por médico generalista com capacidade de atender toda a família, o 
que é substituído em 2000 pelo clínico geral com habilidade para o atendimento de todos da família, independentemente de sexo e de idade. Esta modificação afastou do PSF uma característica importante na estrutura da estratégia que se contrapõe ao modelo hegemônico, que é a abordagem da comunidade garantida na categoria de médica de generalistas. Em 1920, Bertrand Dawson, médico inglês, criticou a separação das práticas preventivas e curativas do modelo flexeneriano e propôs a atuação de médicos generalistas capazes de atuar sobre indivíduos e comunidade (NOVAES 1990).

Entre as atribuições das equipes do PSF que caracterizam novas práticas e que sinalizam a mudança do modelo, estão aquelas que se referem à promoção da saúde, ao desenvolvimento de processos educativos, voltados à recuperação da auto-estima, à melhoria do auto-cuidado (MS/ 1997). Na forma de ações mais abrangentes, a equipe deve promover ações intersetoriais, promover, através da educação continuada, a qualidade de vida e contribuir para a construção de um meio ambiente mais saudável. Para a consolidação do SUS, a equipe deve discutir, de forma permanente, junto à comunidade, o conceito de cidadania $\mathrm{e}$ incentivar a participação popular nos Conselhos Locais de Saúde e Conselho Municipal de Saúde.

O PSF prescreve atribuições para cada profissional e desenvolve eixos de intervenção prioritários, determinados pela Norma Operacional da Assistência (NOAS/ SUS 2001), editada pelo governo federal, como qualquer outro programa vertical.

Em MENDES GONÇALVES (1994), ao definir práticas de saúde, torna-se mais claro o cenário desejado com as mudanças das práticas tradicionais. O autor define que a prática de saúde é uma prática social articulada na totalidade do social, isto é: dimensões econômicas, políticas e ideológicas. A partir desta definição, o modelo tradicional não será superado só pela mudança da prática profissional, mas as práticas de saúde para o SUS deverão ser construídas pela sociedade na responsabilidade das políticas públicas econômicas 
e sociais (Brasil CFB art.196. 1988), na abrangência das políticas de saúde eleitas pelas três esferas de governo e nos limites das estratégias e dos profissionais.

MERHY (1998 p.104) refere que a possibilidade de mudança através do PSF será possível à medida que se aprofunde o entendimento conceitual do trabalho em saúde, portanto faz-se necessário superar a fragmentação dos saberes e promover a interação entre os profissionais e entre estes e a comunidade. A fragmentação dos saberes nas unidades de saúde da família está bem caracterizada no saber médico e o saber dos enfermeiros que, tradicionalmente, pertencem a equipes de trabalho em unidades de saúde e hospitais, mas realizam ações independentes.

Em PEDUZZI e PALMA (2000), são explicitados os conceitos que qualificam as equipes de trabalho em saúde, esclarecendo a diferença que deve ser entendida entre o que denominamos de equipe multidisciplinar ou interdisciplinar. Os autores referem que o prefixo "multi” traduz a justaposição de trabalhos, preservando o saber prático e teórico de cada profissional, o que não contribui para a interação entre os profissionais e entre as suas práticas. A interação entre os profissionais e suas práticas seria o objetivo das práticas interdisciplinares.

No conjunto articulado de práticas de saúde, práticas dos serviços de saúde e práticas dos profissionais de saúde sobre um território, consolidar-se-á a mudança esperada pela Reforma Sanitária. A mudança da prática médica nos propósitos da grande mudança torna-se frágil e dependente do contexto dos serviços, mas é na transformação do processo de trabalho do médico, na relação com o território, com os pacientes e nas relações das equipes de trabalho que o processo de mudança deverá ser construído, sobretudo por ser o principal item para a reorganização do trabalho no PSF, isto é: "substituir as práticas tradicionais", como está no documento de 1997, as práticas novas deverão conter sinais característicos de um novo modelo. 
As novas habilidades, necessárias ao desempenho profissional dos médicos do PSF, ainda não caracterizadas tecnicamente e indefinidas como posição ideológica, precisam ser identificadas para serem reconhecidas como possibilidade de mudança.

Os profissionais devem superar as dificuldades de ouvir as demandas dos pacientes, reconhecidos como locus de singularidade, e definir necessidades específicas, como também incorporar as diversidades locais para compreensão da promoção, prevenção e recuperação da saúde no âmbito coletivo.

O grande desafio no desenvolvimento das atividades do PSF manifesta-se na forma como o médico opera o conceito de saúde, decorrente da multiplicidade de fatores, para propor intervenções integrais, que devem se contrapor às atividades especializadas e fragmentadas. Ou as práticas dos médicos do PSF, mesmo com novas denominações, são práticas velhas?

As equipes do PSF dos municípios são compostas por profissionais com vínculos trabalhistas diferenciados e introduziram no sistema de saúde dos municípios brasileiros uma forma de contratação terceirizada e a contratação de pessoas sem qualificação específica na área de saúde. Os profissionais das equipes de PSF de Vitória estão distribuídos segundo a forma de contratação discriminada na Tabela II.

Tabela II - Número de profissionais do PSF e forma de contratação, Vitória/ ES, 2002.

\begin{tabular}{|c|c|c|c|}
\hline Regime contratual & Médico & Enfermeiro & Aux. de enf. \\
\hline Estatutário & 03 & 14 & - \\
\hline Contrato temporário & 47 & 08 & 116 \\
\hline IESP/MS ${ }^{*}$ com complementação & 01 & 02 & - \\
\hline
\end{tabular}

Fonte: Departamento de Assistência à Saúde da Secretaria Municipal de Saúde de Vitória, Vitória, 2002.

* Profissionais médicos das especialidades básicas com vínculo empregatício do Instituto Estadual de Saúde Pública e do Ministério da Saúde . 
Os médicos do PSF de Vitória receberam Treinamento Introdutório, oferecido e coordenado pela Secretaria Estadual de Saúde do Espírito Santo (SESA/ES). O curso foi estruturado em quatro módulos que abordaram os conteúdos necessários para o desempenho das novas atividades e foram ministrados de forma a inserir os profissionais na filosofia do Programa, além de desenvolver habilidades no uso das ferramentas para as novas práticas, incluindo a abordagem da família, o diagnóstico das comunidades e o planejamento por problemas prioritários de saúde.

No município de Vitória, a oportunidade de aperfeiçoamento dos médicos na prática clínica é dada pelo Programa de Educação Permanente (PEP), que tem por objetivo adequar a formação médica para os que não possuem especialização em medicina familiar. A equipe de instrutores municipais, criada pelo Decreto 10914, de 29 de julho de 2001, é formada por médicos estatutários com treinamento específico em metodologia de ensino e exercem a função de Educadores Permanentes. Estes médicos permanecem com suas especialidades originais, sendo três pediatras, três clínicos e sete ginecologistas, agrupados em quatro regiões de saúde, formando, em cada uma delas, um Grupo de Aperfeiçoamento Profissional (GAP), no qual se discutem temas específicos, definidos pelo grupo de médicos de família de cada região.

Em 2002, foram discutidos 11 temas da clínica médica e, em 2003, apesar de novos assuntos introduzidos nos grupos de estudo, vinte e seis temas focalizaram patologias específicas, dois temas abordaram sintomas de relevância na clínica médica (cefaléia e dor pélvica) e dois temas de importância para a Saúde Pública: doenças de notificação compulsória e atestado de óbito.

O GAP da Região de São Pedro está localizado na Policlínica de São Pedro. Composto por quatro educadores permanentes que dão suporte a onze médicos. Os educadores fazem ambulatório de referência em suas especialidades, na Policlínica de São Pedro, atendendo os pacientes encaminhados pelos médicos de família da região e em cada USF, acompanhando o médico do PSF no ambulatório de demanda organizada para a sua especialidade (SEMUS /PEP 2002). 
No ano de 2002, a Secretaria de Políticas de Saúde, Departamento de Ações Básicas do MS, publicou uma avaliação do PSF em 10 grandes centros urbanos, incluindo o município de Vitória, com o objetivo de analisar os fatores limitantes da implantação do programa. Este documento defende, ao avaliar o PSF como porta de entrada do sistema, que o primeiro requisito é que o programa seja acessível à população e que sirva de ponto de entrada no fluxo pela rede assistencial na busca coordenada pelo generalista (Ministério da Saúde, 2002, p.111), não se referindo ao clínico geral, conforme documentado nos cadernos da Atenção Básica (2000). Ao ser avaliado quanto à percepção dos profissionais do PSF como porta de entrada do sistema, 64\% dos médicos de Vitória concordaram, enquanto $41 \%$ discordaram e afirmaram que a população procura a rede convencional e os hospitais.

Para avaliar a integralidade da atenção, o estudo selecionou indicadores específicos para as atividades inseridas em quatro eixos: garantia da atenção integral, segundo o tipo de atividades realizadas; garantia de atenção integral, segundo o tipo de demanda atendida; atividades extra-muros e ações intersetoriais que foram realizadas na semana anterior à pesquisa. Neste eixo, os resultados apresentados foram: 22,6\% dos médicos realizam atividades de educação em saúde e $25,8 \%$, realizam atividades em grupo. Dos médicos entrevistados, $77,4 \%$ realizam consultas médicas e apenas 32,3\%, atendem a demanda espontânea.

Quando interrogados sobre a promoção de reuniões com a comunidade, 73,0\% dos profissionais de nível superior da equipe afirmam realiza-las, mas apenas 6,3\% desenvolveram esta atividade na semana anterior; com relação à visita domiciliar, 100\% realizam, mas, na semana anterior, 77,8\% realizaram-nas. Para 57,1\% dos profissionais de nível superior, a equipe desenvolve atividades fora do setor saúde, mas apenas $23 \%$ respondeu que a equipe realizou contatos com outros órgãos, e, quando perguntado se realizou na semana anterior a pesquisa, este percentual cai para 4,3\%. Apenas 19\% dos entrevistados de nível superior de 
Vitória consideram muito satisfatória a articulação com outros setores sociais para resolver os problemas da comunidade, mas $84 \%$ afirmam que a equipe deve relacionar-se com outros órgãos públicos, Organizações Não Governamentais (ONG) e com a sociedade civil para resolver os problemas. $81,0 \%$ acham muito satisfatória a capacidade de conhecer os principais problemas de saúde da população.

É difícil emitir juízo de valor sobre as opiniões apresentadas, quando são agregadas atividades de enfermeiros e médicos, cujas competências no PSF são diferenciadas, mas chama atenção no eixo da integralidade da assistência sobre os propósitos das consultas médicas que podem reproduzir o modelo flexeneriano. As variáveis dicotômicas para atividades que desenham um novo modelo, mesmo quando realizadas, deixam de mostrar a qualidade dos conteúdos relacionados e construídos com a apropriação dos territórios.

\section{IDENTIFICAÇÃO DO PROBLEMA}

O município de Vitória, desde sua municipalização, vem buscando construir um novo modelo tecnoassistencial em saúde para o SUS. Percorreu caminhos inovadores na construção de um modelo de saúde e, a partir de 1998, escolheu o PSF como estratégia de mudança. Mudança de modelo, apoiada na estrutura da rede básica tradicional que se aprimorou na municipalização.

Sendo o PSF uma intervenção que produz efeitos a partir da prática dos agentes de implantação*, esta prática pode produzir efeitos positivos, que constroem os efeitos esperados

\footnotetext{
* Por implantação é considerado o uso apropriado e intensivo da intervenção. O grau de implantação de uma intervenção pode interferir nos efeitos esperados. A implantação tem dependência dos fatores do contexto (entre eles os agentes de implantação) que delimita os efeitos da estratégia. (DENIS 1997)
} 
pela intervenção, ou negativos (DENIS 1997, p.59). As práticas dos agentes são estratégias fundamentais para o alcance dos objetivos da intervenção, e estas estão delimitadas nas atribuições estabelecidas para cada agente do PSF.

Sendo o médico um agente de implantação do PSF, sem o qual a estratégia não viabiliza diagnóstico e tratamento, sua prática, na medida em que rompe as práticas tradicionais do modelo médico hegemônico, torna-se elemento importante para construção de um novo modelo de saúde. Já as ações de promoção e prevenção podem ser desenvolvidas por todos os componentes das equipes.

Neste contexto questiona-se: a prática médica no PSF contribui para a construção de um novo modelo para o SUS?

- A prática médica que está sendo desenvolvida no PSF contribui para a construção de um Modelo de Saúde que admite a multicausalidade com determinação social no processo de adoecimento e busca a qualidade de vida das pessoas?

Para responder a esta intrigante indagação e identificar a forma como os médicos podem estar fazendo a mudança, o que eles fazem e como eles fazem, é objeto deste estudo a prática médica desenvolvida pelos profissionais do PSF na Região de Saúde de São Pedro. 


\subsection{Objetivo Geral}

Analisar a prática médica no Programa de Saúde da Família e sua contribuição para a mudança do Modelo Tecnoassistencial em Saúde do município de Vitória, através da identificação de elementos sinalizadores nas atividades médicas que caracterizem a operacionalização de conceitos fundamentais na mudança do modelo.

\subsection{Objetivos Específicos}

- Analisar se as atividades desenvolvidas pelos médicos na rotina do PSF, no espaço físico da unidade ou nas atividades extra-muros, sinalizam a construção de um novo modelo.

- Identificar os limites e as possibilidades da mudança do modelo tecnoassistencial em saúde, através dos elementos considerados sinalizadores de mudança na prática médica 


\section{O CAMINHO METODOLÓGICO}

Para o desenvolvimento do estudo, foi escolhido a abordagem qualitativa para coleta e análise dos dados por ser considerada o mais apropriada para evidenciar em que práticas os médicos possibilitam a mudança de modelo tecnoassistencial. O método favoreceu a descoberta da dimensão não conhecida e não revelada nos estudos quantitativos.

Segundo CONTANDRIOPOULOS (1999), a informação sobre fatos já ocorridos, onde estão envolvidos atitudes e comportamentos é melhor caracterizada através de entrevistas, e estas foram utilizadas de forma aberta, para permitir aos atores a externalização do que fazem, como fazem e porque fazem, com que valor e com que opiniões, não registradas em nenhum sistema de informação da área de saúde. Os médicos entrevistados falaram sobre a prática do PSF e a mudança individualmente vivida.

Segundo SERAPIONE (2000, p.191), os métodos qualitativos analisam o comportamento humano sob o ponto de vista do ato, são orientados ao processo e assumem uma realidade dinâmica, o que remete as declarações a terem validade no contexto do PSF até o momento da entrevista.

Para análise dos dados, utilizou-se o estudo do conteúdo das falas dos médicos sobre os fatos de seu dia-a-dia nas unidades de saúde, havendo a preocupação de não interpretá-los no referencial do senso comum, como o de muitas das opiniões sobre o PSF, mas articular as palavras ditas, transcritas e analisadas com as circunstâncias em que esses fatos ocorrem. Segundo MINAYO (1994), "Todo o esforço teórico para o desenvolvimento de técnicas visa, ainda que de forma diversa e até contraditória, ultrapassar o nível do senso comum e do subjetivismo na interpretação e alcançar uma vigilância crítica” (p.203).

A busca das informações contidas nos documentos internos da Secretaria Municipal de Saúde - Plano de Ação Anual, Relatório de Gestão, Relatórios Setorias, Relatórios de Oficinas de 
Planejamento, Avaliação do Programa de Educação Continuada e outros - , foi utilizada para o desenho aproximado das circunstâncias do momento estudado.

Ainda em MINAYO (1994), citando a crítica de Orlandi e Pêcheux sobre a análise de conteúdo, refere que estes autores consideram que a esta técnica "toma o texto como pretexto e o atravessa só para demonstrar o que já foi definido a priori pela situação". Mesmo que muitos dos elementos do PSF sejam definidos, a priori, pelo contexto, já que o programa é prescritivo -, nomeia o parâmetro que delimita o território, caracteriza a unidade, diz o que deve ser feito pelos profissionais de saúde e como vai ser a equipe -, a técnica de análise de conteúdo foi escolhida como a mais adequada para a compreensão dos elementos que podem demonstrar novos instrumentos ou novas formas de atuação dos médicos com a possibilidade de construir um novo modelo.

Três categorias foram definidas, com base no referencial teórico adotado neste estudo, e reafirmadas nas entrevistas exploratórias, realizadas com alguns médicos das primeiras equipes de PSF da cidade de Vitória. Esses médicos apontavam algumas mudanças que ocorreram nas suas práticas, referenciando separadamente as ações que desenvolviam como equipe e o que estavam fazendo com seus pacientes, sendo o território pouco caracterizado como objeto de intervenção. Com o desenvolvimento das entrevistas no grupo de médicos selecionados, estas categorias tornaram-se foco nas falas dos médicos e direcionaram a discussão dos resultados.

A análise guiou-se pelas três categorias relacionais escolhidas: o médico e o território, o médico e o paciente ou usuário e o médico e a equipe, lugar onde se pode melhor demonstrar a construção de um modelo para o SUS substitutivo do modelo existente.

Os temas relacionados a cada categoria foram buscados na fala dos médicos em qualquer momento da entrevista, não obedecendo aos limites e à ordem das perguntas, mas à descoberta de "núcleos de sentido" que se relacionavam com as categorias. Não houve uma prévia definição dos temas, eles se definiram em conformidade com o surgimento dos núcleos de sentido que emergiram e incorporaram novos referenciais teóricos ao estudo. 
Não existe a possibilidade de generalizações, tanto do método quanto dos resultados, por tratar-se de um Estudo de Caso na perspectiva da pesquisa qualitativa, mas poderá ser um estímulo aos profissionais que fazem avaliação de programas de saúde e que utilizam somente a pesquisa quantitativa. Alguns documentos foram buscados para aumentar a validade interna do estudo (DENIS e CHAMPAGNE 1997).

\subsection{Caracterização do Local do Estudo}

A Região São Pedro, antiga área de lixão da cidade, passou por importante processo de urbanização nos últimos vinte e cinco anos. É uma das seis regiões de saúde da cidade de Vitória. Sua ocupação, ocorrida do final dos anos 70 até o início dos anos 90, consolidou-se em uma área de extenso manguezal, onde havia uma pequena vila de pescadores, Ilha das Caieiras.

Em 1977, os migrantes que chegaram ao Estado em busca de empregos, gerados pelos grandes projetos industriais, construíram suas casas sobre o manguezal. Em 1983, a história da mobilização popular da região foi registrada no filme "Lugar de Toda a Pobreza", que se transformou em uma denúncia das condições de vida daquele lugar.

Em 1990, a Prefeitura de Vitória iniciou uma política de melhoria para a região com a inauguração da Usina de Triagem e Compostagem de Lixo que, até os dias atuais, gera empregos para os moradores. Vários outros projetos ajudaram a melhorar a qualidade de vida dos moradores. Entre eles, foi criado o Projeto São Pedro, no qual foi possível associar urbanização com preservação. Novos projetos estão sendo implementados, aproveitando os recursos naturais e gerando emprego e renda para a região como o Rota Manguezal (ecoturismo) e o Projeto Terra, que oferecem moradia e infra-estrutura à população de baixa renda. A qualidade de vida da população acompanhou os investimentos nas áreas de saúde, educação, saneamento básico, 
segurança e geração de emprego e renda, mas ainda é informal a principal fonte de renda dos moradores, que ganham em torno de 1 a 3 salários mínimos (SEMUS 2000).

Com uma população de 32.305 habitantes distribuídos em onze bairros entre mar e o maciço central da Ilha de Vitória, há 14 escolas municipais do primeiro grau, quatro Unidades de Saúde, uma Policlínica, um Centro de Controle de Zoonoses Municipal, uma Unidade de Apoio aos Desnutridos da Universidade Federal do ES, uma Faculdade Privada - FAESA, com ambulatório de odontologia, muitas igrejas, banco, correio e um comércio diversificado. É a região onde existe a maior possibilidade de resolubilidade na assistência à saúde pela capacidade de oferta de serviços, estruturada no Projeto Integrar e com cobertura de 100\% de PSF.

As quatro unidades básicas de saúde são Unidades de Saúde da Família que se responsabilizam por quatro territórios. Na Tabela III, estão representados os bairros que compõem cada território de responsabilidade das USF, totalizando doze bairros de características diferenciadas na sua formação, que se distribuem à esquerda e à direita da principal via de acesso à Rodovia Serafim Derenze.

Tabela III - Relação das Unidades de Saúde da Família e os bairros que compõem cada território do município de Vitória. Vitória, ES. 2003.

\begin{tabular}{|c|c|}
\hline Unidades de saúde da família & Bairros \\
\hline USF Ilha das Caieiras & $\begin{array}{c}\text { Ilha das Caieiras, S. Pedro I, S.Pedro II, } \\
\text { S. Pedro IV e Condusa. }\end{array}$ \\
\hline USF Santo André & Santo André, Redenção e S. Pedro III \\
\hline USF São Pedro V & S. Pedro V, Nova Palestina e Conquista \\
\hline USF Resistência & Resistência \\
\hline
\end{tabular}

Fonte: Departamento de Assistência à Saúde da Secretaria Municipal Saúde de Vitória, 2002. 
As equipes da Região de São Pedro estão distribuídas de acordo com o número de famílias estabelecido pelo MS. A necessidade de aumento da capacidade de atendimento médico em algumas USF foi solucionada pela introdução de médicos de horário integral fora das equipes (médicos para alívio de demanda). A Tabela VI apresenta a distribuição das equipes e profissionais médicos por USF.

Tabela IV - Número de equipes mínimas e de profissionais médicos em cada Unidade de Saúde da Família da Região de São Pedro. Vitória .ES.2002.

\begin{tabular}{|l|c|c|}
\hline $\begin{array}{c}\text { Unidade de Saúde da } \\
\text { Família }\end{array}$ & $\mathrm{N}^{\mathrm{o}}$ de equipes & $\begin{array}{c}\mathrm{N}^{\mathrm{o}} \text { de profissionais } \\
\text { médicos }\end{array}$ \\
\hline Ilha das Caieiras & 03 & 03 \\
Santo André & 03 & 03 \\
São Pedro V & 03 & $03+01^{*}$ \\
Resistência & 02 & $02+01^{*}$ \\
\hline Total & 11 & 13 \\
\hline
\end{tabular}

Fonte: Departamento de Assistência à Saúde, SEMUS, Vitória. ES 2002

* médicos extras para alívio de demanda 


\subsection{Sujeitos da pesquisa}

Médicos do PSF da Região de São Pedro, de ambos os sexos, que concordaram em participar da pesquisa com consentimento livre e esclarecido (Anexo 2). Esses médicos não representam a totalidade dos médicos das USF da região, porém os que possuíam os seguintes pré-requisitos:

- $\quad$ estar nas equipes do PSF da Região de São Pedro em junho de 2003;

- $\quad$ trabalhar por mais de 2 anos nas equipes de PSF;

- $\quad$ pertencer a equipes completas.

- Um dos pré-requisitos anteriormente escolhido para a caracterização dos entrevistados e que poderia ter um papel importante no comportamento dos médicos tradicionais, o Treinamento Introdutório para o PSF, deixou de ser considerado por não ter sido um curso obrigatório, não terem sido concluídos todos os módulos previstos e não ter sido oferecido a partir do ano 2000.

\subsection{Procedimentos para coleta de dados}

Após aprovação do projeto de pesquisa pelo Comitê de Ética em Pesquisa da Faculdade de Saúde Pública da Universidade do Estado de São Paulo (COEP), foi encaminhado o pedido de consentimento ao Secretário Municipal de Saúde de Vitória, tendo sido qualificado como relevante, de acordo com parecer do Núcleo de Apoio a Pesquisa e do Departamento de Assistência a Saúde da SEMUS.

A apresentação do projeto de pesquisa para os médicos ocorreu nos grupos de estudos mensais do PEP, com cooperação do coordenador do programa. A ausência dos médicos nesta atividade e a paralisação das reuniões do PEP, durante o mês de janeiro, dificultaram o primeiro 
contato com alguns médicos, necessitando de retornos sucessivos, durante os meses de fevereiro, março e abril de 2004. Mesmo assim, três médicos foram procurados diretamente em suas unidades, após contato telefônico.

A dificuldade dos médicos selecionados em dispor de um horário para receber o entrevistador, devido a outros compromissos profissionais fora do horário do PSF, levou a um agendamento longo, com intervalo maior, de 15 dias, entre entrevistas. Algumas com um tempo possível de duração, determinado pelo entrevistado, como tempo disponível para responder as perguntas.

As entrevistas com os médicos foram realizadas durante o primeiro quadrimestre de 2004. Quatro delas foram realizadas na própria unidade de saúde onde os médicos trabalhavam; duas nas residências dos profissionais; uma no local de realização de um dos encontro do PEP.

Todos os médicos foram devidamente esclarecidos quanto ao objetivo do estudo, quanto à liberdade para a possibilidade de recusarem-se a participar e quanto à sustentação do anonimato. Apenas um médico selecionado deixou de ser entrevistado por estar, na ocasião das entrevistas, passando por problemas particulares que o impediram de receber o pesquisador.

\subsection{Instrumentos de coletas de dados}

A obtenção dos dados realizou-se por entrevista aberta, composta de uma seqüência de perguntas norteadoras que, feitas oralmente pelo entrevistador, poderiam ter esclarecimento, como recomenda LAVILLE e DIONNE (1999). Por tratarem-se de questões que envolviam o cotidiano dos serviços de saúde, não houve necessidade de esclarecimento nas perguntas, porém, certamente um pouco de insistência por parte do entrevistador sobre alguns aspectos das questões (Anexo 3). 
As respostas foram gravadas em fita magnética e transcritas, literalmente, pela pesquisadora, após escuta minuciosa, o que a levou encontro de uma pequena parte do mundo subjetivo de cada médico do PSF.

Para aumentar a validade interna do estudo de caso (DENIS e CHAMPAGNE 1997), foram utilizadas fontes de dados documentais, relativos à distribuição das atividades médicas na USF, que estão registradas no Boletim Único de Produtividade da Secretaria Municipal de Saúde (BUP), para o ano de 2003, e no Sistema de Informação Ambulatorial (SIAB), para o mesmo ano, documentos internos da SEMUS, relativos ao Departamento de Avaliação Controle e Auditoria e do PEP.

O banco de dados do SIAB emite um relatório com número de consultas e de visitas domiciliares, realizadas por cada médico, mas os dados relativos à educação em saúde são consolidados por equipe de nível superior (médico e enfermeiro), não permitindo a caracterização exclusiva do médico. Para a informação sobre educação em saúde por profissional do PSF, foi utilizado o banco de dados do BUP, que tem registrado todos os procedimentos realizados por cada profissional, desde que as informações tenham sido registradas em planilha própria. 


\section{ANÁLISE E DISCUSSÃO DOS RESULTADOS}

Ao se considerar os relatos de como os médicos do PSF estão realizando suas ações nas Unidades de Saúde da Família, da Região de São Pedro, busca-se, no trabalho do médico, a ação que transforma o modelo, não no sentido de desqualificar as ações dos médicos, mas de reconhecer seus limites e possibilidades relativas.

\subsection{Características dos entrevistados}

Dos oito médicos selecionados, sete foram entrevistados e trabalham há mais de dois anos nas Unidades de Saúde da Família. Ingressaram no programa pelos mais diversos motivos, desde única possibilidade de emprego até a vontade de permanecerem nas unidades de saúde em que vinham desenvolvendo suas atividades como médicos pediatras, ginecologistas ou clínicos, anteriormente à implantação do programa.

Apenas um médico não possui especialidade médica, mas referiu experiência prévia com o PSF em uma localidade da região metropolitana de Vitória. Dois médicos possuem especialidades fora do modelo biomédico tradicional, um é acupunturista e o outro, homeopata, o que não os diferenciou do modo como o trabalho médico está sendo desenvolvido no PSF, principalmente quando foi levada em consideração a relação contextualizada do adoecimento.

Os médicos não possuem formação acadêmica para exercerem a especialidade de médicos generalistas e não foi observada homogeneidade nas respostas quanto à importância do “Curso Introdutório para o PSF”, oferecido pela Secretaria Estadual de Saúde. Este curso foi considerado um momento de capacitação, mas não ofereceu habilidades para o trabalho. Foi referência unânime de capacitação efetiva o PEP, da SEMUS/Vitória, que tem uma metodologia do "fazer com a gente nas unidades". 
Entre os três médicos efetivos municipais, um médico solicitou afastamento do PSF para fazer parte da Coordenação Municipal do Programa de Adolescentes, e outro foi transferido para uma equipe do PSF, recentemente implantada em outra Região de Saúde (agosto de 2003). Este fato tem sido observado entre médicos e enfermeiros do PSF, efetivos municipais que, após alguns anos de atividade no programa, solicitam mudança de local de trabalho e, na maioria das vezes, fora do PSF. O pedido de afastamento entre os médicos de contrato temporário não é usual, e, entre os entrevistados, um médico espera o término do contrato para afastar-se definitivamente do programa.

A maior parte dos médicos entrevistados está insatisfeita com o PSF, e toda a perspectiva de mudança esperada por eles "está longe de acontecer".

\subsection{0 médico e o território}

O território do PSF é a base estrutural do programa que delimita o espaço geográfico, a partir do número de famílias, delimitando, assim, a área geográfica de atuação das equipes. Cada USF deve ter, no máximo, três equipes (isto é definido pela SMS), e cada equipe responsabilizase por 600 a 1000 famílias. De acordo com Caderno de Atenção Básica (MS-2000 p.22), o mapeamento da área onde será implantado o PSF deve ocorrer depois que o número de equipes e o número de agentes comunitários estão estabelecidos. A partir deste momento, as microáreas são mapeadas, de acordo com o número de famílias. Uma área de abrangência de uma USF é um território composto por um conjunto de microáreas.

O território como espaço de atuação de profissionais de saúde, áreas de abrangência das Unidades de Saúde, espaço das atividades das visitadoras sanitárias dos Centros de Saúde ou espaço dos inspetores sanitários, isto é, limites territoriais, tem suas origens nas organizações administrativas da Saúde Pública desde seus primórdios. Consolidou-se na Moderna Saúde 
Pública como espaço operativo das ações sanitárias, nas cidades do Séc. XIX, onde as estratégias para enfrentamento dos problemas davam-se a partir das comunidades onde os médicos elaboravam uma descrição detalhada do lugar, de todas as características e pontos de perigos (topografia médica). Anteriormente, na Alemanha do Séc. XVIII, os médicos tinham a responsabilidade de um Distrito e visitavam todas as cidades e aldeias naquela área geográfica para sistematizar as características das populações, do meio ambiente e as doenças (ROSEN 1994 p. 175).

O PSF refere a possibilidade de agir sobre o território e tem, na área adscrita, a Unidade de Saúde e, na divisão espacial das microáreas, as duas formas de delimitar a população sobre a qual serão desenvolvidas as ações de saúde. A partir da metodologia enunciada na publicação do MS/ 2000, não existe possibilidade de delimitar territórios, mas áreas de abrangência. O conjunto de profissionais das UBS não tem dúvidas de qual território ( área de abrangência) está sob a responsabilidade das equipes e referem com presteza a delimitação geográfica do espaço de implantação do PSF.

Em MENDES (1996), a definição de território vai além do espaço físico, sendo sua dinâmica caracterizada pela denominação de "território - processo" onde opera a vigilância em saúde e, neste lócus, a ação transformadora será direcionada. Para o autor a vigilância em saúde é uma forma de resposta social organizada para dar solução aos problemas de saúde logo terá de "recompor o fracionamento do espaço coletivo de expressão da doença" ( p.243).

Territorialização ou marcação de territórios tornou-se, metodologicamente caracterizado, a partir de 1989, sob a iniciativa da Área de Infra-estrututa de Sistemas de Saúde da Organização Panamericana de Saúde, Grupo de Apoio á Implantação de Sistemas Locais de Saúde, que disseminou a diferença entre territorializar ou apenas demarcar topograficamente (UNGLERT 1995). 
Territorialização em Saúde é definida como um processo de apropriação do espaço por distintos atores sociais, sendo a representação deste espaço muito mais que uma área geográfica, tendo um perfil epidemiológico, administrativo, tecnológico, político e social que o caracteriza e se expressa em permanente construção, portanto territorialização é o passo fundamental para caracterizar a população e seus problemas de saúde (UNGLERT 1995). A apropriação do espaço local é apenas uma forma sistematizada de conhecer a comunidade para prática do planejamento ascendente, levando em consideração problemas identificados e priorizados pela equipe da unidade de saúde e a comunidade (p. 9).

Falar de Território pautado nas reflexões dos geógrafos, dos antropólogos, da antropologia médica e da sociologia está contido o conceito de espaço cotidiano onde a cultura dá a consciência aos atores de pertencer a um grupo, de pertencer à história (SANTOS 1997) e que são apropriados porque transformam o espaço social, com nova lógica temporal (NICOLAS 1998). Provavelmente não é esse o território do PSF, já que a demarcação geográfica antecede o conhecimento dos grupos sociais existentes na localidade.

Para MINAYO (1998), Território é o lugar de entendimento do processo de adoecimento, onde as representações sociais do processo saúde-doença envolvem as relações sociais e as significações culturais e, para se minimizar a dificuldade dos sujeitos envolvidos na construção das intervenções de saúde, há de não se medir esforços para a implementação do planejamento participativo nos territórios que agrega aos profissionais de saúde o saber das pessoas do território legitimamente apropriado. A partir destas referências, são apropriados dos territórios de atuação do PSF somente os Agentes Comunitários de Saúde, sujeitos do lugar e, quanto maior for o tempo de residência na área (o PSF admite mais de dois anos de residência na área), mais apropriado, porque se consolida uma relação de sujeito que faz o lugar. 
Quando a maioria dos médicos entrevistados chegou em São Pedro, os territórios já tinham sido delimitados pelas oficinas de territorialização, que aconteceram durante o ano de 1995, e mesmo aqueles que acompanharam o movimento de territorialização da cidade não poderiam reconhecer as características do lugar após tantas transformações, tantos projetos de urbanização. Durante a implementação do PSF na região, não foram oportunizadas novas oficinas que favorecessem o exercício constante de reconhecimento e delimitação de territórios.

O diagnóstico situacional de saúde do território não foi incorporado na prática dos serviços como um norteador das ações programadas. As necessidades da população não são reconhecidas e não existe uma identificação sistemática dos problemas comuns nas microáreas.

Este fato se comprova no direcionamento que é dado ao planejamento das atividades na USF que, realizado uma vez ao mês, organiza a divisão das tarefas na equipe: as visitas sociais, visitas domiciliares, algum evento da Secretaria Municipal de Saúde e as rotinas do atendimento médico conforme estabelecido pela Secretaria Municipal de Saúde. Neste planejamento não são incluídos os problemas locais ou as reivindicações das comunidades.

Existe planejamento mensal, a partir da necessidade de satisfação da demanda por atendimento médico, que se operacionaliza na organização da agenda médica. Esta agenda pode ser modificada, se acordado na equipe.

"Na minha unidade se planeja o agendamento, mas não existe a partir das necessidades ou que possa se desenvolver para promoção e prevenção da saúde, conforme o programa preconiza, não existe tempo, não dá para sair do esquema de consultas. A gente ainda faz alguma prevenção. Mas promoção?” (entrevistado 3) 
“... o planejamento das equipes ocorre para a divisão das tarefas...” (entrevistado 4 ).

“... Quando eu entrei na minha unidade, já tinha um tempo montado, porque na unidade só tem duas salas e três equipes, então sempre um tem que estar desenvolvendo uma atividade fora da unidade, enquanto dois ficam atendendo. Às vezes a gente faz metade do horário, apertaaqui, aperta- ali pra poder caber todo mundo...o que vai variando, lá já tinha um fluxo, de acordo com a demanda a gente vai se organizando a cada mês, a gente faz uma reunião pra fazer planejamento..." (entrevistado 1).

A paisagem da região é mirada diariamente pelos médicos e pode ser reveladora das condições de desenvolvimento da comunidade e de todo o ambiente físico. Representa o lado visível do espaço, fotografias sucessivas dos caminhos percorridos pelo médico para chegar à unidade e nas visitas domiciliares (quando solicitadas pela sua equipe) pressupõem uma atitude de valorização das atividades extra-muros da USF e do que se vê. Portanto, desenvolve um olhar crítico sobre a realidade para que a imagem tenha um valor.

De acordo com os médicos do PSF entrevistados, eles estão saindo da unidade, estão realizando atividades externas aos consultórios e nomeiam algumas características da comunidade, mas não conhecem o território. Os médicos relatam que é a enfermagem que mais se ocupa das atividades fora da unidade, em uma relação estreita com os Agentes Comunitários de Saúde, o que oportuniza o maior conhecimento do território.

Os médicos sabem que existem muitos problemas e reivindicações da comunidade que não chegam até eles, ficam sob responsabilidade da coordenadora da unidade que se reúne com o Conselho Local de Saúde.

“... existe um Conselho que se reune com a coordenadora da unidade e, se eu não me engano... eu nunca participei porque é sempre depois das cinco..., depois do atendimento ou 
quando no horário do atendimento não coincide de estar liberado naquele horário.” (entrevistado 2)

Quando perguntados sobre problemas além da capacidade de atuação profissional, os médicos referem os problemas sociais da área, mas não conhecem as estruturas de amparo social e até a Pastoral da Saúde de atuação marcante na região parece ter-se afastado dos serviços de saúde, após a implantação do PSF.

A metodologia de planejamento participativo, ascendente, poderia ajudar os médicos na identificação dos movimentos populares do território que ao agregar a comunidade, agregaria a Pastoral, que tem, na apropriação do território e na solidariedade, a fundamentação do seu trabalho de cuidador e seria um facilitador na identificação de práticas tradicionais, a partir das necessidades locais de saúde.

“... Quando eu era só pediatra na área, acho que a pastoral agia mais. Quando chegou o OS, parece que se afastou, eu ainda mando se cadastrar para pegar a multimistura... mas não sei se acriança é acompanhada." (entrevistado 2)

“A Pastoral se envolvia, antes quando eu era pediatra, há 3 anos atrás... vamos dizer era o único envolvimento da criança... único alicerce da criança...” (entrevistado 3).

“Agora acabou. Quem fazia muito isso era Dra. H... todas as quintas feiras ela sempre ia para Pastoral, ela abraçava esse trabalho e levava. Como mudou? Porque a coordenadora não é médica, isso se perdeu um pouco." (entrevistado7)

“Tem uma senhora que trabalha na Pastoral que é cliente nossa e que sempre pede para eu fazer uma palestra, mas eu estou em dívida, eu acabei não indo. Mas ela sempre fala..." (entrevistado 7). 
“... lá elas desenvolvem um trabalho legal, mas assim, era um trabalho meio paralelo". (entrevistado 6)

Os médicos com menos tempo de trabalho na região não reconhecem a Pastoral como movimento de promoção da vida nas comunidades. Não há referência espontânea, nas entrevistas, e é um indicativo de que não existe uma identificação importante com o movimento comunitário, havendo, portanto, a necessidade de tempo e permanência para se conhecer o território e todas as suas saídas.

Na relação de apropriação dos territórios, estabelece-se o vínculo onde o profissional é reconhecido como pertencendo ao território, e a população se reconhece na Unidade de Saúde. Para MERHY (2000 p.138), "É ter uma relação, é integrar-se, com a comunidade em seu território, no serviço, no consultório, nos grupos e se tornar referência para o usuário, individual e coletivo". Mas, no mesmo parágrafo, o autor estabelece a grande diferença da interpretação burocratizada dos serviços de saúde ao explicitar que: "Criar vínculos implica em ter relações tão próximas e tão claras, que nós nos sensibilizamos com todo o sofrimento daquele outro, daquela população".

PICHON-RIVIERE (2000), denomina de vínculo: “a maneira particular pela qual cada indivíduo se relaciona com outro ou outros, criando uma estrutura particular a cada caso a cada momento" No terceiro capítulo, sob o título de Vínculo, Comunicação e Aprendizagem, o autor esclarece que "no vínculo está implicado tudo e complicado tudo" referindo-se à abordagem Freudiana das estruturas psíquicas e estes são condicionados por outros vínculos, acumulados nos sujeitos que estabelecem uma relação. A reflexão aqui apresentada não objetiva explicar a relação do vínculo entre o médico do PSF e o seu paciente ou sua área de abrangência, mas uma tentativa de mostrar a complexidade de alguns conceitos usados no PSF e indefinidos operacionalmente.

"Olha, isso aqui é um estresse grande, cansativo, a gente leva problema para casa, é uma..., a gente recebe ameaças, afrontas, ouve desaforos e ,como conseqüência, faz um quadro depressivo, um quadro de hipertensão ou aquela glicemia de transição, eu , um dia desses, 
cheguei aqui e fui medir minha glicemia e estava 206. Eu tinha passado uma raiva, mais tarde já estava 90, é altamente estressante, a exigência é muito grande, a demanda é muito grande e os pacientes não estão preparados, eles querem que os médicos estejam à disposição deles". (entrevistado 5)

“... o que faz adoecer é que elas (as médicas) se envolvem demais com os pacientes... ficam falando o tempo todo dos pacientes e levam esses problemas para casa, quando eu saio, deixo os problemas aqui." (entrevistado 4 )

“o médico fica doente, a carga horária é muito grande, todo mundo está com as agendas lotadas, a gente se envolve muito com os pacientes. Ele está ali o dia todo, todo dia...” (entrevistado 6).

Ao se ter como base de interpretação os documentos oficiais do PSF, o vínculo a ser estabelecido entre os profissionais das equipes e as famílias é a responsabilidade por um conjunto de ações bem delimitadas e com soluções pré-estabelecidas através dos programas. O contraditório é a apropriação da USF pelos usuários e o vínculo na sua versão de obrigação em resolver os problemas. Nesta modalidade de apropriação e vínculo, os conflitos se estabelecem no confronto do que parece estar entendido pelos usuários como obrigações médicas e, no entendimento dos médicos, como de sua responsabilidade.

Algumas frases, em contextos não direcionados ao relato de vínculo, foram importantes na descoberta deste conflito:

"Você é minha médica... Você tem que resolver...Tudo, qualquer coisa, até as questões sociais... Eles acham que você sabe de tudo, às vezes tem coisas que você não tem conhecimento, eles acham que você tem que dar um jeito..." (entrevistado 1).

“... Os encaminhamentos para problemas puramente médicos que o paciente volta e cobra da gente para resolver o problema. Eles já chegam dizendo que veio para que a gente 
resolva o problema, ele já sabe qual o médico é responsável pela sua família e que precisa de ser resolvido o problema." (entrevistado 2)

“... Atendo muita demanda espontânea que é colocada no encaixe. É um peazão..Deixa o médico preso. Os pacientes acham que o médico está à disposição deles...” (entrevistado 4).

"Sei que em Vitória tem, mas aqui na minha área é mais calmo, por eu estar mais tempo e alguns profissionais estão há mais tempo e você passa a ter um relacionamento. A gente conversa. Uma coisa muito importante é conversar muito aberto com eles, outra coisa é estabelecer uma programação e manter aquela programação que eles acabam encaixando naquilo." ( entrevistado 7)

Na organização do PSF, o vínculo como responsabilidade do serviço de saúde, sobre os pacientes individuais ou sobre o coletivo, se estabeleceria à medida em que fossem assegurados a porta de entrada e o caminho dentro do sistema de saúde, isto é, a complementariedade das ações de saúde para resolutividade dos casos.

No significado de vínculo administrativo, o agendamento teria o papel de garantir e colocar o indivíduo na rede de cuidados em todos os níveis de complexidade tecnológica. Mas só é agendada parte da demanda existente nos territórios para aqueles indivíduos considerados pertencentes a grupos prioritários de agravos na visão biomédica dos problemas. Este agendamento deixa sem possibilidade de atenção os indivíduos sadios sujeitos a riscos de agravos. Sendo assim, o vínculo dos médicos seria um vínculo com parte do território, principalmente com doentes.

Para que o agendamento consolidasse o vínculo do serviço de saúde com o território, o cadastramento das famílias e de seus componentes teria um sentido de oportunizar, em tempo real, a estrutura populacional, seus riscos e seus determinantes e, a partir dele, se estabeleceriam as prioridades e uma agenda (listagem) que ordenasse e garantisse o atendimento dos indivíduos e de suas famílias. Logo, conhecer o cadastro ou usar as informações do cadastro seria uma forma 
de conhecer o território e estabelecer vínculo entre a comunidade e o serviço de saúde na responsabilização pelos usuários.

Ao se adotar o conceito de vínculo como responsabilização em lidar com a vida das pessoas, este vínculo estaria dependente das qualidades individuais de cada profissional e poderia ser observado na demonstração do carinho, da afeição ou, até mesmo, da piedade nas relações interpessoais, porque, no sistema de saúde, lidar com a vida é muito mais que mantê-las.

GUILBERT (1994), no seu livro sobre a ciência da convivência, revela algumas regras para construir convívios, não apenas como arte de conviver, mas como transformação numa ciência do convívio, já que dele depende o bem estar da humanidade. Se a implantação de equipes deve ser implementada e se os vínculos não administrativos são complexos. No capítulo 49, o autor esclarece um ponto importante com relação à escolha da convivência, isto é, com quem se quer conviver, o que não acontece por acaso, mas no ambiente humano que o autor denomina de Acaso Grupal. Não existe oportunidade de escolhas entre os médicos e pacientes, mas existe a motivação dos pacientes ao procurarem o serviço que é a cura de seus sofrimentos. É nesta escolha por uma motivação unilateral que se dá a escolha racional e consciente de se iniciar uma relação que, não correspondida, torna-se desarmônica.

“... mas é claro que o limite da atuação médica está nas questões sociais, foi isso que nos deixou adoecer, que nos faz adoecer, eu até adoeci... Pode ser que agora, se organizando melhor o Comitê da Vida, porque, para não deixar morrer uma criança, toda a comunidade vai precisar se mobilizar... e o que ficava só dentro da área da saúde pode ser que melhore..." (entrevistado 3).

“eu não adoeci porque estou acostumado com tragédia, eu trabalho no Infantil..." (entrevistado 2).

"É difícil, a gente sente muito frustrada, a gente quer meio interferir, mas você fica um pouco com medo. A gente está ali na comunidade, então, até que ponto você pode interferir para 
não causar desconforto para a família e para você que vai ficar ali na comunidade.Você vai ficar ali." (entrevistado 6)

É no lidar com situações relacionadas à vida das pessoas, às suas condições sociais e seus problemas que os médicos precisam fazer escolhas técnicas e exercitar a ética. $\mathrm{Na}$ área da saúde, o ensino e o exercício da ética limitaram-se apenas às normas de comportamento para indivíduos de determinada categoria profissional, e esta tolerou a desumanização praticada pelos profissionais de saúde. Segundo FORTES (1998), uma nova ética deve considerar como valor essencial a garantia do respeito à dignidade humana, para além da deontologia médica. Neste referencial abrangente, a ética está sustentada nas qualidades individuais e nas características adquiridas pelos médicos nas suas experiências pessoais e profissionais. Como as experiências anteriores e as habilidades adquiridas a partir das experiências são parte da arte médica (SCHRAIBER 1995), poucos médicos estarão de prontidão para desenvolver uma nova arte, principalmente nos lugares onde as redes causais de adoecimento expõem uma trama não reconhecida pela elite intelectual de profissionais que, provinda de uma categoria social que não ofereceu experiências de convivência com as diversidades sócio-econômico-culturais, não terá caminho para pensar soluções para indivíduos ou para o coletivo, o que também não é promovido pela escola médica.

“... tem muita coisa que a gente fica de mãos atadas, porque alcoolismo e droga, essa semana tive um casal na minha frente, um casal que fuma maconha o dia inteiro e os dois querem parar de fumar porque tem um filho de dez anos, né! A mulher foi primeiro, daí eu acho importante você conhecer a família, primeiro pela mulher que falou meio tímida, na outra semana, levou o marido pra fazer exames. Ela foi, só que de fato como eu vou trabalhar esse casal? Eu não tenho espaço na minha agenda pra fazer esse tipo de abordagem. É, né! Eu posso até fazer um atendimento de grupo, alguma coisa, né! Então, eu encaminhei para o psiquiatra, porque, no caso deles, eu acho, poderia ter o tratamento psicológico e mandar para o CPTT não vai conseguir, então você fica naquela impotência, né! Então, e agora? Então tem coisas que são complicadas." ( entrevistado 1) 
“As coisas sociais são muito emperradas, eu não acho que se consiga resolver com agilidade. O médico está acostumado a trabalhar com muita agilidade, ele chega a uma solução... Aquilo ali, não, tem que ligar num sei pra quem! Tem que ligar pro juizado! Tem que ligar pro Conselho. Tem que não sei pra quem pra quem liberar não sei o quê. Eu não aguento! Demora demais. Tentava a Assistente Social, mas é muito demorado.” (entrevistado 6)

Os entrevistados que exercem a medicina há mais tempo parecem entender melhor as situações sociais que se apresentam nas queixas, mas operam intervenções que, técnica e comprovadamente, são estruturadas no saber médico flexeneriano.

A estrutura do conhecimento na formação de médicos flexenerianos não exclui, no entanto, a possibilidade de uma nova ética ou um vínculo, que, após a interação do primeiro contato com o paciente, se aprofunde na interação do contexto e se amplie as relações com outros níveis de atenção para novas possibilidades terapêuticas. Para que isto ocorra, há necessidade de novas habilidades para além da capacidade intuitiva dos profissionais, que pode ser desenvolvida, no médico, através de outros saberes que, incorporados na formação ou na educação continuada, ajudem no entendimento do primeiro contato.

“Eu acho que é um vínculo afetivo, é! Até nas reuniões, eu mesmo falo, isso aqui é um espaço pequeno, é como isso aqui fosse ótimo. Na verdade, é que muita coisa disso é de uma pessoa que aprendi a admirar, que muitos anos fez aqui. Tem muito da Dra H... que era uma pessoa que não tinha um papel muito burocrático. Ela queria resolver. Eu acho que é muito do médico também, né. Você está acostumado a atender e dá um fim. Os outros profissionais né, eu noto, que não são assim, dão atenção têm tudo, mas não dão um fim.” (entrevistado 7)

Há de se ter cuidado, quando, no PSF, se desloca o foco de responsabilidade da estrutura do Sistema de Saúde na sua representação local, que é a unidade, e nos outros níveis de gerenciamento do SUS, focalizando a responsabilidade nas equipes, expondo os profissionais a tantos problemas, que poderiam ser minimizados na capacidade do Sistema Municipal de Saúde 
em propiciar a prestação de serviços adequados, que passam a desconsiderar o outro sujeito ou sujeitos com os quais precisam estabelecer convivência ética.

"Eles ficam sabendo que a medicação vai chegar e vêm aqui à tarde...- é porque não chegou a medicação? Aqui, para diabético não vem medicação e a gente se confronta com os pacientes." (entrevistado 5)

"Os encaminhamentos para problemas puramente médicos, que o paciente volta e cobra da gente para resolver o problema. Eles já chegam dizendo que veio para que a gente resolva o problema, ele já sabe qual o médico é responsável pela sua família e que precisa de ser resolvido o problema." (entrevistado 2)

"Eles cobram. Eles reclamam, mas não me cobram porque eu já explico que é problema da prefeitura, que é problema de vaga, que não é problema meu e que, depois do encaminhamento, é lá que vão resolver" (entrevistado 6).

\subsection{O médico e o paciente}

Os médicos do PSF atendem a população das microáreas adscritas as suas unidades para consultas individuais sob a forma de demanda organizada para programas específicos e por demanda livre no chamado acolhimento, onde um médico de cada equipe, pelo menos duas vezes por semana, ocupa-se da demanda espontânea em um horário de trabalho, totalizando 8 horas semanais. Além destas duas modalidades de organização do atendimento individual, as intercorrências clínicas de pacientes cadastrados são encaixadas no atendimento diário do médico de referência da microárea de residência do paciente.

A maioria dos médicos conhece seus pacientes que vêm à unidade, mas não guardam os nomes de todos. 
"Não conheço, conheço de vista uma grande gama, conheço uma grande gama de seus problemas, os pacientes em si...” (entrevistado 5).

"Não, você não tem tempo para isso, até porque você não atende a família, você atende indivíduos, você atende paciente minguado, a meu ver, é pronto atendimento no programa de saúde da família... porque hoje vem uma mãe trazendo uma criança, ela pode marcar até duas crianças." (entrevistado 5)

"Conheço a família dos acamados. Os que vêm aqui por algum motivo, durante a consulta, quando outros já vieram, dá para dar uma olhada nos prontuários que estão no mesmo envelope.” (entrevistado 3)

"As famílias são conhecidas quando todos os membros são pacientes e são individualmente problemas de saúde que recorrem à unidade a procura de consulta médica." (entrevistado 3)

"No geral não se aborda a família. Quando o caso de uma criança desnutrida que a mãe sai para trabalhar e a vó mora no mesmo quintal. Hipertensos, acamados, no caso do cuidado e o filho mora longe, manda chamar, para depois não ficar falando" (entrevistado 6).

Os médicos não conhecem todas as famílias sob sua responsabilidade, não existe oportunidade de visitas domiciliares com este objetivo.

"É impossível conhecer todas as famílias ... algumas não vão ao serviço". "Eles mudam muito de rua, mudam de equipe, ali dentro do bairro mesmo." ( entrevistado 2).

Segundo os relatos, as consultas agendadas, que organizam administrativamente a demanda dos programas de saúde da mulher, da criança, do idoso, de hipertensos e diabéticos, 
priorizam as atividades de: prevenção do câncer de colo uterino, o pré-natal, a puericultura, atenção medicamentosa aos pacientes portadores de hipertensão e diabéticos.

Os programas prioritários, instituídos pelo MS, possuem coordenadores municipais para cada área programática que planeja as metas municipais e um profissional da USF, de qualquer equipe, responsabiliza-se pela coordenação das ações na unidade. Não existe, atualmente, uma meta local ou por equipe.

A população está cadastrada, mas o cadastro não é a base para o cálculo de cobertura dos programas ou para o aumento da capacidade instalada das unidades. São os pacientes que procuram o agendamento para suas consultas nos dias pré -estabelecidos pela unidade.

“...o agente de saúde, trabalhando nas visitas, dizem os dias de marcação de consultas." (entrevistado 7)

Em pesquisa sobre a satisfação dos usuários desta região, foram apontadas a dificuldade de inclusão de novos pacientes nos programas, a dificuldade de acesso para consultas de urgência e a dificuldade de marcar consultas de retorno (DAC/SEMUS nov/2003). Os médicos falam da sobrecarga de consultas, mas ainda é motivo de insatisfação dos usuários.

Há possibilidade de implantação de programas especiais, como o programa do adolescente e o programa de controle da tuberculose e hanseníase, mas na dependência das características pessoais dos profissionais das equipes, em uma proposta não unânime entre os médicos da cidade de Vitória. 
“...vem estabelecidos da Secretaria, ...os programas...” (entrevistado 5).

"...consultas médicas para programas. No caso da Hanseníase, está acertado que um médico e uma enfermeira que trabalham às quartas feiras vão atender todos os pacientes do território. Eu tenho atendimento para adolescente porque gosto e tive oportunidade de organizar o grupo. Na nossa região, só nossa unidade tem atendimento para adolescentes.” (entrevistado 3)

“... eu e a enfermeira R... Nós atendemos toda a hanseníase de São Pedro....todos estão capacitados para ver uma mancha e mandar na quarta- feira que eu e R....estamos lá...” (entrevistado 2 ).

“...nós aqui atendemos os pacientes de tuberculose, os de hanseníase, é melhor mandar para o dermatologista... eu já fui treinado muitas vezes, eu sou efetivo, quem tem contrato temporário é mais difícil..." ( entrevistado 7).

A distribuição das consultas agendadas não é resultado das necessidades indicadas a partir do diagnóstico local e não objetivam garantir a cobertura para grupos específicos de agravos. O quantitativo de consultas necessárias para cada grupo de pacientes vai se adequando à medida que a demanda espontânea traz para a unidade novos casos, obrigando-a a um rearranjo na marcação. A coordenação da unidade decide.

“...Cada equipe faz sua agenda, desde que seja atendendo... Minha agenda já está pronta, algumas vezes dá uma modificadinha, mas a base dela já está pronta, desde que a gente começou. Foram feitas oficinas pra gente chegar a uma agenda que se adaptasse a nossa região, a nossa procura." (entrevistado 2)

“Cronograma, você diz! Quem faz o cronograma é a coordenação e a enfermagem. A gente que é médico só toma conhecimento, tanto que tem uma programação que até hoje estou meia perdida...... Olha, segunda feira a senhora vai atender gestante! Na quinta vai atender 
ginecologia e preventivo!.....Deveria ser os problemas mas importantes da área, mas aqui já existe, como se diz..." (entrevistado 5).

"Nós estamos no meio de uma crise, não tem médico aqui. Já saíram 2. Tem proposta para outro município. Ela conversou, não podem fazer nada.” (entrevistado 7)

SCHRAIBER (1990), na introdução do livro Programação em Saúde Hoje, chama atenção para o uso de alguns termos cujo conteúdo significativo pode não retratar a realidade que se quer descrever. A autora, naquele momento, referia-se à programação, mas a reflexão torna-se pertinente quando se examinam o discurso teórico do PSF e as características das atividades desenvolvidas, cujas denominações podem deixar de qualificar corretamente a realidade existente, "parecerão, portanto, sempre conceituações pertinentes, porém sempre incompletas, para dar conta de representar a diversidade do real" (p.13). Exemplos encontrados nas falas dos médicos são o acolhimento, visita domiciliar, palestra, educação em saúde, planejamento e programação, prevenção.

Os médicos fazem acolhimento dos pacientes, consultando aqueles que thes forem encaminhados, resolvem algumas queixas e encaminham os que precisam de outros tipos de intervenção.

“o paciente surtou... ele fica um tempão no acolhimento..... sentado.....tem muita coisa que a gente fica de mãos atadas...” (entrevistado 1).

"todo dia tem acolhimento. Cada dia tem uma equipe que faz acolhimento, o paciente que adoece de repente pode ser atendido no acolhimento." (entrevistado 2)

“...ela vem para o acolhimento e diz que tem pressão alta. No acolhimento se atende tudo...vai pra sala... nos 10 minutos, detectar a causa daquela hipertensão e manda procurar a enfermeira que vai fazer o cadastro, a partir daquele moment, ela vai pertencer ao grupo" a", "b" ou "c", em cada micro área." (entrevistado 4) 
“...tenho demanda espontânea 1 vez por semana... tenho demanda espontânea às quintas feiras, a demanda espontânea é chamada acolhimento, mas durante a semana, se aparecer alguém, nós também somos obrigados a atender no chamado encaixe..." (entrevistado 5).

O acolhimento, como prática de serviços de saúde, tem como objetivo principal a garantia de acesso e "escutar e dar respostas positivas, capazes de resolver os problema de saúde da população" (MERHY 1994 ). Não existe uma clara definição do acolhimento realizado pelos médicos,sabe-se, apenas, que está centrado no atendimento da demanda espontânea e que, por algum motivo, recorre à unidade e não entra pelo agendamento. O autor, no terceiro capítulo, propõe um projeto de intervenção em busca da mudança do modelo (p.136) e, no sub-item problemas, o enfretamento do problema "acesso" toma um caminho que se concretiza num espaço por ele chamado de Unidade de Acolhimento e que deve apresentar os seguintes resultados (p.137).

- Tratar humanizadamente toda a demanda;

- Dar respostas a todo demandante;

- Discriminar os riscos, as urgências e emergências;

- $\quad$ Dar respostas para a demanda individual e coletiva;

- $\quad$ Produzir a informação necessária para a unidade de assistência;

- $\quad$ Ficar alerta, junto à unidade de assistência, para ler os problemas do ponto de vista de sua dimensão coletiva e abrir possibilidades de novas opções tecnológicas de intervenção.

No acolhimento, o direito do cidadão seria garantido e, mesmo sendo centrado nas consultas médicas, poderia ser a porta de entrada do cidadão no sistema de saúde, oferecendo oportunidade para que, a partir daí, as equipes multiprofissionais dessem conta da integralidade. Nas unidades do PSF, os caminhos percorridos pelos pacientes sem acolhimento não são de conhecimento dos médicos. Este fato potencializa o desconhecimento do território, já que a 
demanda espontânea é a voz do território e a demonstração das necessidades percebidas. Não conhecer o que não chega à unidade dificulta ações de prevenção e promoção da saúde.

“... das 40 horas por semana, eu faço 8 hs de demanda espontânea, e sobram 32 para atendimento dos hipertensos, diabéticos, todas as gestantes, todas as puericulturas." (entrevistado 6)

“As urgências não chegam no acolhimento, são encaminhadas para a Policlínica,

... as urgências não têm horários... chegou com pressão alta, febre alta, convulsão, a gente manda para a policlínica.ou qualquer outro problema,como dor aguda, suspeita de envenenamento, a gente manda para a policlínica." (entrevistado 5)

"Não tem que atender não. Lá em São Pedro é uma coisa que tem lá que é a Policlínica que pode ter todos os defeitos, mas aquilo ali a gente não tem em outros lugares do município, por exemplo, chega uma intercorrência, não tem acolhimento, não tem que atender, o enfermeiro faz o encaminhamento ou o próprio coordenador faz." (entrevistado 6)

"a gente tem um cartaz que sinaliza os sintomas que são para urgência e explica que são para a Policlínica." (entrevistado 3)

Fazer acolhimento no PSF, enquanto modalidade do trabalho médico desenvolvido pelos entrevistados, não mostra posssilidade de mudança de modelo tecnoassistencia,1 apesar de ser uma forma de fazer cumprir ou de se esforçar em cumprir a acessibilidade. Ao acolher, revelamse as necessidades, mas há de desenvolver a responsabilização profissional para propor intervenções capazes de impactarem os processos sociais, produtores de saúde e de doença, além do que se apresenta no espaço da USF.

Não é garantida estruturalmente a resolutividade dos casos que chegam pelo acolhimento ou os pela agenda para pacientes prioritários. O SISS São Pedro não oferece uma 
estrutura adequada a todas as necessidades locais e não existe mecanismo seguro de relação do PSF com outros serviços de saúde.

"Nós temos um resultado muito ruim como os encaminhamentos para o PEP. Nós temos, .... horrível com o encaminhamento para especialistas, nós temos problemas com os encaminhamentos para a Policlínica, porque muita gente imaginava, mas eu não imagino mais não, que você teria um suporte ,ou seja, quando você encaminha para os especialistas e que você já fez aquilo que estava ao seu alcance. Mas, na maioria das vezes, o paciente retorna da mesma forma ,ou seja, eu não sei mais o que fazer a diferença toda ... dificilmente eu encaminho e dificilmente eu peço auxílio de alguém, não sei..., eu pulo isso aí , encaminho diretamente aos centros de referência, Santa Casa, Hospital das Clínicas, converso com os colegas, ligo... então estou encaminhando." (entrevistado 7)

SCHRAIBER (1990) refere que o modelo com priorização de consulta responde com a completude do ato assistencial, ao diagnosticar e tratar as queixas, e que as intervenções baseadas na busca ativa dos casos, no diagnóstico precoce, nas ações terapêuticas e nas ações de prevenção e promoção podem não responder com prontidão às demandas contidas nas queixas dos pacientes. Em São Pedro, a convivência de práticas que, tradicionalmente, foram exercidas separadamente: o trabalho clínico e o trabalho sanitário que se consolidam na prevenção e na promoção da saúde têm sido dificultadas pela demanda por atendimento médicos que chega de forma vigorosa, caracterizada como reivindicação constante dos usuários.

Dentre as atividades médicas desempenhadas pelos entrevistados, fica demonstrado que os médicos das USF não são agentes importantes no exercício do trabalho sanitário.

“As palestras são para grupos. O PSF, o princípio dele é prevenção e a gente só previne educando. A palestra é muito importante... eu acho que devia fazer mais. A demanda é muito grande e a gente acaba ficando preso na unidade, a gente devia fazer mais reuniões educativas, eu acho." (entrevistado 6) 
“As palestras geralmente são feitas pela enfermagem.” (entrevistado 3)

"Não há tempo, enquanto os enfermeiros trabalham com os agentes, orientando as palestras, eu estou na sala atendendo ou fazendo visitas com uma delas. Raramente tem palestra. Depois que a Policlínica montou uma enfermaria no auditório, não teve mais palestras." (entrevistado 5)

"é, nós fazemos ação comunitária como a gente fala, que envolve os grupos e as palestras né!."Então a gente quase não tem tempo para isso, para fazer as palestras e participar dos grupos, quando você consegue participar do grupo de hipertenso, não pode fazer de adolescente, quando faz de adolescente, não pode fazer de gestantes. Então, essa parte fica mais por conta da enfermagem, da enfermeira." (entrevistado 2)

A educação em saúde é uma atividade desenvolvida pelos programas de saúde pública, no modelo tecnoassistencial sanitarista, fundamentada nos bons hábitos. Fortemente influenciada pelas doutrinas higienistas, não refletiu sobre os elementos da cadeia de causalidade, consolidando-se com o objetivo de mudar hábitos, valores, crenças e comportamentos considerados nocivos à saúde.

O instrumento mais usado para levar a educação em saúde à população tem sido as palestras educativas ou reuniões educativas ou reuniões de grupo, em que o método fica dependente da escolha de quem vai fazer a atividade e sua capacidade na condução dos temas. Esta atividade, quando desenvolvida de forma participativa, está adequada aos princípios do SUS, aberta aos questionamentos e ao incentivo ao debate da situação geral de saúde da comunidade na perspectiva de transformar a realidade.

Na década de oitenta, a Divisão de Educação em Saúde do Governo Federal divulgou, como referência conceitual, uma Educação em Saúde como prática social que contribuísse para o desenvolvimento de uma consciência sanitária crítica (MS/DNES, 1989), mas este instrumento, no PSF, não tem oferecido um processo de capacitação aos indivíduos estando exclusivamente 
direcionada a grupos de risco específico com a finalidade de transmitir normas de comportamento mais saudáveis.

"Eles nunca pediram (sobre temas especiais) a gente coloca nas reuniões de adolescentes, aí teve uma certa ocasião que eu perguntei, eu fui falar mais sobre método anticoncepcional, dei uma pincelada sobre DST e eles pediram uma próxima reunião para falar mais sobre DST. A gente aproveita este espaço de reunião para ver se está solicitando exames. Por ex, você pega um grupo de adolescente e pergunta: alguém aqui já fez VDRL? E HIV? Não! Quem quer fazer? Aí a gente vai, leva o prontuário e deixa tudo anotadinho.” (entrevistado 1).

“... mais ou menos isso que a gente faz, que é a necessidade básica, mas, mesmo pra isso, o tempo já é escasso, porque tem que fazer tudo, então não dá, você vai fazer reunião..., bom seria que você pudesse fazer na metade do período, pudesse fazer as atividades coletivas, fazer visitas, desenvolver as reuniões porque às vezes você tem que colocar 30 ou 40 pessoas em uma reunião só porque você não dá conta, não tem dia, não dá tempo de fazer, então é complicado." (entrevistado 1).

A visita domiciliar, no contexto da organização dos serviços de saúde, traz a oportunidade de poder relacionar o adoecimento com os fatores da vida familiar e social observados no lugar. É uma prática tradicionalmente desenvolvida pelos profissionais da enfermagem com a finalidade de dar assistência às famílias.

Tema específico no Manual de Enfermagem para o PSF (IDS/USP 2001) é apresentada como um instrumento técnico com a finalidade de conhecer as condições de vida das famílias. No Manual de Condutas Médicas no PSF, o instrumento "visita domiciliar" está caracterizado pelos autores DALMASO e NEMES (2001), ao abordarem o tema Promoção da Saúde, como um instrumento de "suporte social" isto é: dar informações, apoio emocional e fornecer recursos técnicos e materiais para que as pessoas se cuidem e se protejam. 
Nas visitas realizadas pelos médicos do PSF, a consulta médica está deslocada do ambulatório da rede de assistência para dentro das casas, caracterizando o uso de um instrumento da saúde pública, agora, como espaço do trabalho clínico. Esta oportunidade pode ser um passo para uma integração das práticas, quando reorganizada e potencializada.

Pacientes acamados ou com dificuldade comprovada de deambulação são atendidos com visitas médicas no seu domicílio, após a comprovação desta necessidade pela enfermeira da equipe do PSF.

"Na visita, de acordo com a pessoa, é que... de acordo com o paciente: é um acamado, é um hipertenso com seqüela de AVC e não pode deambular, você vai ver as condições gerais do paciente, fazer prescrição, cuidados, é uma consulta médica, eu até já colhi preventivo." (entrevistado 6)

"acamados, tem muito acamado crônico e que foram incluídos. Eles sentem falta, quando passamos 45 dias sem visitar, eles dizem que já fazem 3 meses. Visita para família sadia não dá tempo.”(entrevistado 3).

“As visitas domiciliares, cada equipe tem um dia para fazer. Tudo programado. Quando tem uma urgência naqueles pacientes que a gente atende em casa, os acamados, a enfermeira vai à frente para ver se precisa de atendimento médico. Se for, a gente tenta ir o mais rápido possível" "a enfermeira é a primeira a fazer a visita porque o agente comunitário sempre leva o problema para ela, depois que chega até a gente."

(entrevistado 2).

O quantitativo das atividades desenvolvidas pelos médicos entrevistados no ano 2003 e registradas nos bancos de dados oficiais da SEMUS/Vitória, Boletim Único de Produtividade (BUP) e o Sistema de Informação Ambulatorial (SIAB), está apresentado na Tabela V referindose à: consultas médicas, visitas domiciliares e à educação em saúde (cada grupo com 10 a 15 
pessoas), demonstrando como o trabalho desenvolvido concentra a maior parte da carga horária dos médicos em consultas médicas.

Tabela V - Produção de atividades médicas no PSF, por entrevistado, por procedimentos específicos, Região VI, Vitória, Jan/ Dez 2003.

\begin{tabular}{|c|l|l|l|l|l|l|l|}
\hline Procedimentos & ent.1 & ent.2 & ent.3 & ent.4 & ent.5 & ent.6 & ent.7 \\
\hline Consultas médicas* & 596 & 814 & 928 & 221 & 266 & 354 & 297 \\
\hline Visitas domiciliárias* & 07 & 16 & 4 & 08 & 2 & 61 & 3 \\
\hline Educação em Saúde (Palestras) ** & 8 & 1 & & & & 3 & \\
\hline
\end{tabular}

Fonte: BUP/SEMUS/NPD abril de 2004 - SIAB/ SEMUS/ DASS 2003

* SIAB

** dado exclusivo do BUP, com sub-registro dos médicos do PSF.

"No horário da agenda, aí a gente marca essas reuniões. São essas mais fixas, como é o caso de hipertensão, diabetes que são pacientes que precisam estar com a receita em dia e, se você for marcar consulta para todo mundo, você não consegue, aì a gente faz isso no horário da reunião, a gente marca, a gente sempre está dando algum esclarecimento de alguma coisa, além daquela rotina toda de falar sobre a doença a gente põe alguma coisa a mais por ex. hoje foi o pessoal dos dentistas falar sobre câncer de boca. Aproveitar este espaço da reunião para estar falando outras coisas."

(entrevistado 1).

Os médicos do PSF desenvolvem os programas de hipertensão e diabetes de forma verticalizada e prioritariamente agendados nas unidades. Não existem relatos de outras patologias e, se foram identificadas, não foram incluídas no acompanhamento prioritário. Os pacientes ingressam nos programas já doentes, e a prevenção primária ${ }^{*}$ dos agravos não é realizada. 


\section{$5.4 O$ médico e a equipe}

A dificuldade para buscar na falas dos médicos a referência de um trabalho em equipe se deu a partir da escolha dos parâmetros com os quais se poderia qualificar o trabalho que se desenvolve no PSF.

Está evidente que existe divisão de tarefas e que os saberes não são compartilhados na equipe, mínima ou alargada, e que a composição com outros profissionais, odontólogos, farmacêuticos, fisioterapeutas, assistentes sociais, possibilitará uma nova forma de organização dos serviços, o que ainda não é a realidade na região estudada.

As atribuições técnicas de cada profissional da equipe do PSF estão registradas no documento do Ministério da Saúde (Brasil, 1998 p.13), sendo enfatizado que estes devem "estar identificados com uma propostas de trabalho que exigem criatividade e iniciativa para trabalhos comunitários e em grupo". Mesmo definidas estas atribuições, não estão acompanhadas de um modelo explicativo de como fazer o trabalho em equipe que não se realiza apenas pela designação, mas quando o processo de trabalho se altera. Neste sentido, as discussões de CAMPOS (1997) sobre núcleo de atuação em que cada profissional preserva suas competências e saberes específicos e campo de atuação dos profissionais onde a responsabilidade e os saberes são comuns a todos de uma equipe estariam adequadas para dar conta da localização das tarefas, num projeto de reforma da divisão do trabalho, para atendimento das necessidades de saúde de um dado território. O núcleo de competência de cada profissional não dá conta da complexidade das necessidades de saúde, mas há que se preservar a competência técnica que protege dos erros.

\footnotetext{
* prevenção primária na HND se refere a vertente epidemiológica com intervenção anterior ao aparecimento da doença.
} 
Os médicos entrevistados desenvolvem suas competências profissionais, núcleo de atuação, aprimorando sua técnica através do PEP, não sendo oferecidas oportunidades de integração entre os médicos e outros profíssionais por ocasião da apresentação de temas que favorecem a abordagem interdisciplinar como: saúde mental, climatério, desnutrição e outros. A coordenação do PEP já se preocupa com uma nova metodologia para o estudo de temas de importância interdisciplinar para serem desenvolvidos em encontros multidisciplinares.

Nenhum entrevistado referiu momentos de discussão na equipe do PSF com a finalidade de resolução dos problemas apresentados pelos pacientes ou que conversam com os outros profissionais que estão na unidade de saúde na perspectiva de mudanças da estrutura do serviço ou para construir consensos. Os médicos encaminham os pacientes principalmente para os assistentes sociais e psicólogos responsáveis pelo atendimento da unidade ou para outros serviços nos casos que julgam necessários.

"Desde que bem selecionadas e outra coisa que as pessoas não, eles cobram muito sem ter a visão, eles cobram muito números, número de visitas, isso não é importante. Eu que conheço a área há muito tempo, a média de visitas mensal é 4 , ou 6 porque não há necessidade dos médicos. Na minha equipe se faz da seguinte forma: as agentes fazem triagem das visitas domiciliares e passam para as enfermeiras que têm um contato mais direto, assim a enfermeira seleciona o próprio auxiliar para fazer a visita, por ex. chegou um paciente que tem que fazer um curativo, às vezes ele já vem com a instrução do curativo e a auxiliar vai a casa e faz. Se houver dúvidas ,eles requisitam a enfermeira e a enfermeira faz a visita. Quando é uma outra visita a enfermeira vai primeiro, faz uma triagem, uma avaliação do caso e chega e fala: oh! Tem que fazer a visita e, no dia da visita, eu vou. Então funciona desta forma. Essa prá mim é a melhor forma. Logo que começou ... é, existia uma propaganda do governo, então, todo mundo queria."(entrevistado 7)

"Não fomos nós, talvez a coordenação, não sei de quem porque nós médicos somos os últimos a saber das coisas. Muitas vezes nem ficamos sabendo! Para você ter a idéia , chegou 
aqui numa quinta-feira uma colega que veio para me substituir porque eu seria removida para outra unidade. E eu não sabia !" (entrevistado 5)

“essa visita é um pouco difícil, tem que levar a assistente social, o médico, a equipe toda e a agente tem que ir... é uma visita muito delicada, às vezes a família pergunta por que é que veio? Ah! tem doente assim... grave, acamado, tem grávida....”. (entrevistado 2).

"Neste caso, a gente encaminha para a Assistente Social. Tem que envolver essas pessoas, porque a prefeitura está montando este serviço fora do bairro, nos já discutimos isso, nos casos de drogas, a gente bater de frente até afeta a gente, tipo uma criança que foi espancada, você denunciar, chamar! Então, nós estamos dentro da comunidade.” (entrevistado 2)

PEDUZZI (2001) apresenta em seu artigo sobre conceito e tipologia de equipes, uma distinção entre equipes que se articulam no trabalho que realizam nas unidades de saúde para alcançar a integralidade das ações e outras que desenvolvem suas tarefas em separado. A autora separa as duas modalidades de equipe, caracterizando-as em: Equipe Agrupamento com justaposição de tarefas e agrupamento dos agentes e Equipe Integração com articulação das ações e interação dos agentes. Em nenhuma das duas modalidades parece estar caracterizado o PSF da Região VI, pois existe uma dificuldade de encontro dos componentes da equipe e existe uma clara hierarquia de decisões no limite das competências técnicas de cada profissional, que já estão acordadas uma vez por mês.

“na reunião de planejamento das equipes ocorre a divisão de tarefas." (entrevistado 4)

"Não, a gente vai acompanhando, mas tem casos que a gente chega ao nosso limite. No PSF, nos treinamentos, eles falam da terapia familiar, mas aqui tem psicólogo que eu encaminho para ela. O problema são os outros profissionais que precisam estar trabalhando na estratégia de saúde da família.” (entrevistado 7)

A falta de consensos na condução da assistência à saúde para as populações em 
territórios com graves problemas sociais expõe a fragilidade dos profissionais que passam a ter necessidade de defender-se individualmente.

"Eu não vou e a Senhora vai vir, quando falei com a enfermeira, ela disse que a senhora tem que ir! O paciente falou. Eu confrontei e os auxiliares foram escondidos." (entrevistado 5)

"Aqui tem muitos problemas sérios: drogas, violência que tem em todo lugar. Eu não tenho respaldo nenhum, não tenho proteção nenhuma para me meter nisso, para fazer isso. Muitas vezes é problema de polícia, problema de estrutura social mesmo. Uma vez fui na casa de um traficante para atender uma criança com paralisia cerebral com 7 anos. Que não vestia roupa, tinha a boca cheia de cárie e parecia que tinha mí́ase. Uma confusão louca. Fomos lá instruímos a mãe e hoje ela veste roupa. O odontólogo começou a tratar e a criança melhorou muito, tem acompanhamento com o neurologista e faz a higiene dela direitinho. Mas uma dessas visitas, as pessoas que estavam presas estavam lá. Até então só estavam lá a mãe a vó e a criança. Quando nós chegamos lá, estavam uns 12 , solto e usando droga. Ou seja, como é que vai se comportar. Conversamos com a mãe, Bom dia! E eles falaram um monte de coisas. Agora que a criança está melhor, ela vem à unidade. E as agentes ficaram...! é por quê? Não sei o quê? e nós não temos nada com isso e nós fomos lá para atender a criança. É num momento desses que vamos numa casa dessa a gente vira refém, a gente ganha um tiro." (entrevistado7).

Os médicos entrevistados demonstraram preocupação em resolver os "casos" que lhes são apresentados pela demanda. Eles querem "dá um fim”, “o médico está acostumado a trabalhar com agilidade, ele chega a uma solução", "quando não consegue, encaminha as referências que poderão resolver o caso".

A forma de atuação dos médicos, em qualquer sistema de saúde, em qualquer modelo, obedece a uma certa consensualidade na forma de ver o mundo, de falar, de escrever, o que, para Byron Good, citado por MENEZES (1998), deve-se a todo o processo vivido pelos alunos de medicina, denominado pelo autor de "práticas formativas". Estas práticas conduzem a um referencial de prática médica que se qualifica no sucesso pragmático. 
Para SCHRAIBER (1993), a medicina é uma prática técnica, científica, que só é reconhecida como eficaz quando é uma ação transformadora. Esta ação transformadora se manifesta concretamente na prática terapêutica, é a relação direta com o sofrimento e "aquilo que alivia".

Quando os médicos do PSF não resolvem, o trabalho médico é incompleto, ineficaz e, para os médicos estudados, como a possibilidade da prática clínica resolutiva ou com "aquilo que alivia”, principalmente na região estudada é pequena, os médicos passam por inúmeros insucessos nos quais o conhecimento científico é corporificado em instrumentos e condutas limitadas.

Há necessidade de uma prática terapêutica expandida (exercícios, bolsa alimentação, dieta, direito da cidadania, cesta básica e etc.), com novas intervenções ou intervenções partilhadas com outros profissionais, o que não é garantido pelo PSF.

“A gente faz tudo e, a meu ver, não faz nada! Não tem uma medicação específica que permita que ela amamente os filhos, isto deprime (...) Insatisfeita, frustada, tem que ter medicação para o paciente". (entrevistado 5)

"É difícil, a gente sente muito frustrada. A gente quer meio interferir (...) "Se é uma coisa não resolvida, o problema bate ali todo dia." (entrevistado 6).

Os pacientes cobram insistentemente a obrigação médica em resolver os problemas e este fato tem raízes históricas na sociedade ocidental, onde o trabalho médico foi legitimado com o objetivo de intervenção sobre o corpo humano. Os pacientes sabem quem têm a responsabilidade por eles, cobram a ação e a resolução. 
“... Eles já chegam dizendo que veio para que a gente resolva o problema, ele já sabe qual o médico é responsável pela sua família e que precisa de ser resolvido o problema." (entrevistado 2).

Foi unânime a opinião entre os entrevistados de que a estrutura física das USFs da região é um fator de impedimento para realização de algumas atividades, principalmente as atividades coletivas, e que existe sobrecarga de trabalho para os médicos que estão nas comunidades com situação socioeconômica mais desfavorecida em comparação aos que exercem PSF em bairro de classe média e classe alta do município de Vitória. 


\section{CONSIDERAÇÕES FINAIS}

As práticas dos médicos do PSF, na região estudada, reproduzem os modelos anteriormente estabelecidos no Brasil, Médico Sanitarista e Médico Privatista, com alguns conceitos utilizados de forma inadequada que, com pouca análise crítica, nomeiam ações na perspectiva de mudança, mas deixam de revelar o verdadeiro direcionamento do objeto das práticas.

As ações/atividades desenvolvidas pelo PSF não se expressam como uma forma particular do agir sobre o processo saúde-doença e têm se direcionado sem constrangimento à doença. Segundo CONTANDRIOPOULOS (1998), "Se as doenças e a saúde não são fenômenos independentes, elas não são, no entanto, redutíveis uma à outra" o que impossibilitaria, neste momento, a intervenção do PSF na qualidade de vida da região. O contexto sistêmico de meio ambiente físico como poluição atmosférica, lixo, condições de trabalho e a difusão de agentes nocivos ao homem e de meio ambiente social que se externaliza nos valores, na cultura e na organização social, não são trazidos para dentro do PSF, e a qualidade de vida se conforma no tratamento. A única questão do meio ambiente que a prática médica evidenciou esteve direcionada à condição de higiene dos lugares.

A enorme contradição entre as propostas do programa e o cotidiano do PSF revela uma crise vivenciada pelos profissionais médicos que, na dimensão subjetiva da relação com o outro, se vêem sujeitos de uma reflexão compartilhada de problemas cujas soluções não estão no domínio de seus saberes e práticas. Não existem instrumentos no PSF para facilitarem o diálogo entre as necessidades que vêm dos usuários e os profissionais sendo que, na relação com o usuário "acolhido", entendê-lo requer uma formação profisssional que facilite a compreensão do adoecer, além dos limites biológicos e sociais para um entendimento psicossocial.

BALINT (1988) refere que todo médico na prática clínica geral deve saber entender o paciente, saber "escutar" as demandas não explícitas que estes trazem para as consultas e que vão 
interferir no processo terapêutico. Na série de estudos de casos clínicos que desenvolveu em seu livro "O médico, seu paciente e a doença", o autor esclarece que os médicos ajudam a organizar hierarquicamente os sinais da doença e, por eliminação, através do exame físico, identificam aspectos psicodinâmicos do adoecimento. $\mathrm{O}$ grande alerta do autor está relacionado às intervenção sobre estes aspectos quando abordados por profissionais inabilitados defensores da "psicologia do senso comum”. Muitas das intervenções baseadas na psicologia do senso comum podem ser consideradas "falácia" pelo seu valor limitado (p. 96).

Nas relações sociais complexas, como nos centros urbanos, o peso do psicossocial tem sido discutido por alguns autores, não apenas como "problema psicológico" do indivíduo ou da relação do indivíduo com sua família. VAITSMAN (1992 ) afirma que o bem-estar físico, psíquico e social é um fenômeno em duas dimensões: uma sócio-cultural coletiva e outra psicológica individual, e que estas não podem ser individualizadas, mas compreendidas no plano simbólico.

Na perspectiva de dar suporte às equipes do PSF, os profissionais não biologicistas e habilitados na abordagem das relações interpessoais, seriam os mais adequados para preencher o grande vazio técnico do programa e ajudarem os médicos a dar um sentido transformador à prática clínica afastando a medicalização.

É no campo das relações interpessoais que se estabelecem a humanização e o vínculo; logo, é preciso que os indivíduos sejam considerados, de alguma maneira, simultaneamente biológicos e psicossociais e, para isto, é necessário que se instrumentalize os profissionais para estas abordagens.

Quando os instrumentos de transformação fizerem parte da prática dos médicos do PSF e dos demais profissionais, a sustentabilidade da mudança e a operacionalização de um novo modelo com possibilidade de tornar-se hegemônico consolidar-se-ão. Não está claro quais são os instrumentos de transformação. $O$ cadastro é um instrumento novo e a visita é 
instrumento velho, mas seriam campos privilegiads para utilização de novas ferramentas, isto é, ferramentas transformadoras.

Os médicos com contratos temporários têm um fator limitante na aquisição de habilidades, de vínculo e de poder de transformação, e este fato é marcante no sistema de saúde municipal. É necessário reavaliação dos contratos de trabalho dos profissionais do PSF.

Todos os médicos têm possibilidade de se qualificar através de um programa de educação continuada, mas o programa não possibilita a discussão de temas fora do saber diagnosticar e tratar, ou seja, para um bom desempenho clínico, o que qualifica cada vez mais o tipo de PSF de consultas médicas.

Há necessidade de que os conteúdos dos conceitos sejam do conhecimento de todos, entendidos por todos e ajudem a organizar um sistema de saúde resolutivo. Existe um discurso que não confere com a realidade das USF e que é apresentado aos profissionais médicos através de documentos oficiais, formais, afastando a possibilidade da reflexão crítica e da autonomia.

Os médicos mudam quando saem da unidade de saúde, aprendem o que já tinham esquecido e, para superar suas dificuldades, recebem educação continuada, mas a concepção do problema de saúde não está mudando.

Os médicos não conhecem o território na concepção primordial que transforma o modelo tratando-o como área de abrangência, geograficamente delimitada. Não existe uma análise sistematizada das condições de vida e da estrutura social que, por vezes, ameaça o próprio trabalho médico, principalmente quando da forma não tradicional de levar consultas médicas fora do espaço da unidade. 
O elevado número de famílias revelou-se um fator de impedimento para o adequado conhecimento do território, mas a pressão da demanda por atendimento médico foi o fator mais importante para que os médicos encontrassem dificuldades para desenvolver atividades de prevenção e promoção da saúde.

Os médicos são referência direta para os usuários, e isto foi construído pelos serviços de saúde que adotaram o PSF. Estão desprotegidos num contexto que não lhes garantem a resolutividade dos casos e que os transformou em porta de entrada do sistema. Há necessidade de uma rede resolutiva para segurança dos serviços básicos e que ofereça qualidade na assistência prestada. O sistema de saúde é de responsabilidade da gestão municipal e não dos profissionais de saúde que muitas vezes procuram resolver os casos, individualmente.

Não existe um espaço na organização do trabalho do PSF nas unidades estudadas que garanta a formação de equipes com capacidade de reflexão sobre a mudança de práticas de saúde individuais e coletivas. Não existe discussão de casos ou situações, de forma sistematizada, que oportunize o ensaio da interdisciplinaridade que, para PEDUZZI (1998) diz respeito à produção do conhecimento, e não existem caminhos formais para o exercício da intersetorialidade. A multiprofissionalidade necessária em áreas de grande risco social está minimamente representada pelos assistentes sociais em todas as unidades estudadas e, em algumas, por psicólogos.

Muitas outras reflexões são desencadeadas em cada fato relido e aparentemente novo, quando se refaz o caminho dos temas, mas o que poderia enriquecer a análise realizada neste estudo seria a observação estruturada das atividades.

A forma como o PSF expõe os profissionais a situações e a condições novas de trabalho não garante, por si só, a mudança das pessoas e de suas práticas. Os médicos precisam de ferramentas novas para ampliação da técnica, uma nova arte que depende intimamente da subjetividade dos médicos, mas que pode ser estimulada desde sua formação acadêmica até uma nova ética que deve também considerar o médico como sujeito da relação médico-paciente numa convivência harmoniosa para sua vida profissional. 


\section{REFERÊNCIAS BIBLIOGRÁFICAS}

Arouca ASSO. O Dilema preventivista. Contribuição para compreensão e crítica da medicina preventiva Campinas 1975. Tese de Doutorado- Faculdade de Ciências MédicasUNICAMP.

Assis M. Educação em saúde e qualidade de vida:Par alem dos modelos, a busca da comunicação. Série Estudos em Saúde Coletiva. IMS/UERJ. 1998;169

Balint, M. O médico, seu paciente e a doença. Rio de Janeiro: Atheneu, 1988.

Breilh J. Epidemiologia, economia, política e saúde. São Paulo: UNESP: 1991. Os modelos epidemiológicos como recurso do projeto capitalista; p. 71-131

Camargo Jr. KN. A Biomedicina. Physis-Revista de Saúde Coletiva. 1997 v. 7, n. 1, p.45-68, 1997.

Campos GWS. A saúde pública e a defesa da vida. São Paulo: HUCITEC. 1992

Campos GWS. Considerações sobre a arte e a ciência da mudança: revolução das coisas e das pessoas. O caso da saúde. In: Cecílio LCO, organizador. Inventando a mudança na saúde. São Paulo: HUCITEC; 1994. p. 29-87.

Campos GWS. Saúde pública e saúde coletiva: campo e núcleo de saberes. Ciência e Saúde Coletiva. 2000; 5: 219-30.

Contandriopoulos AP, Champagne F, Denis JL, Pineault R. A avaliação na area de saúde: conceitos e métodos. In : Hartz ZMA, organizadora. A avaliação em saúde. Dos modelos 
conceituais à prática na análise da implantação de programas. Rio de Janeiro: Fiocruz; 1997. p. 29-47.

Contandriopoulos AP, Champagne F, Potvin L, Denis JL, Boyle P. Saber preparar uma pesquisa. Definição Estrutura Financiamento. $3^{\circ}$ edição. Rio de Janeiro: HUCITEC; 1997.

Contandriopoulos AP. Pode-se construir modelos baseados na relação entre contextos sociais e saúde? Cadernos de Saúde Pública. 1998; 14 (1): 199-206

Denis JL, Champagne. Análise de implantação. In: Hartz ZMA, organizadora. A avaliação em saúde. Dos modelos conceituais à prática na análise da implantação de programas. Rio de Janeiro: Fiocruz; 1997 p. 49-88.

Escorel S. Reviravolta na saúde. Origem e articulação do Movimento Sanitário. $20^{\mathrm{a}}$ ed. Rio de Janeiro: Fiocruz; 1999.

Escorel S. Revirada na saúde. TEMA. 1988; 11: 5-7.

Faria LR. A Fundação Rockfeller e os serviços de saúde em São Paulo (1920-30): perspectivas históricas. História e Ciência da Saúde. 2002; 9(3): 561- 590

Fortes PAC. Ética e Saúde. Questões éticas, deontologicas e legais- Tomada de decisões. Autonomia e direitos do paciente. Estudo de casos. São Paulo: Editora Pedagógica e Universitária Ltda; 1997

Grande São Pedro faz 25 anos. Jornal dos bairros. Informativo da Prefeitura de Vitória, Vitória, 2003 Jan/fev; 2 p. 11.

Hartz ZMA. Pesquisa em avaliação da atenção básica: a necessária complementação do monitoramento. Divulgação em saúde para debate. 2000; 21: 7-14. 
Luz MT. As instituições médicas no Brasil: instituições e estratégias de hegemonia. $3^{\circ}$ edição. Rio de Janeiro: Editora Graal; 1986.

Mendes EV. Uma Agenda para a Saúde. São Paulo: HUCITEC; 1996.

Mendes Gonçalves RB. Tecnologia e organização social das práticas de saúde.

Características tecnológicas do processo de trabalho na rede estadual de centros de saúde de São Paulo. São Paulo: HUCITEC; 1994.

Menezes RA. A epistemologia de Flecke a formação médica. Serie: Estudos em Saúde Coletiva . UERJ/IMS. 1998; 182: 3-11

Merhy EE. O Capitalismo e a Saúde Pública. A emergência das práticas sanitárias no estado de São Paulo. $2^{\text {a }}$ edição. Campinas: Papirus; 1987.

Merhy EE, Cecílio LCO, Nogueira RCF. Por um modelo tecno-assistencial da política de saúde em defesa da vida: contribuição para as conferências de saúde. Saúde em Debate. 1991; 33: 8389.

Merhy EE. A Saúde Pública como Política. Um estudo para reformuladores de políticas. São Paulo: HUCITEC; 1992.

Merhy EE. Em busca da qualidade dos serviços de saúde: os serviços de porta aberta para a saúde e o modelo tecnoassistencial em defesa da vida (ou como aproveitar os ruídos do cotidiano dos serviços de saúde e colegiadamente e reorganizar o processo de trabalho na busca da qualidade das ações de saúde). In: Cecílio LCO, organizaqdor. Inventando a Mudança em Saúde. São Paulo: HUCITEC; 1994. 
Merhy EE, Franco TB. Programa de Saúde da Família: somos contra ou a favo? Saúde em Debate. 2002; 5 (2)

Minayo MCS. O desafio do conhecimento: pesquisa qualitativa em saúde. $3^{\circ}$ edição.

São Paulo- Rio de Janeiro: HUCITEC; 1994.

Ministério da Saúde. Fundação Nacional de Saúde. Programa de Agentes Comunitários de Saúde. Brasília (DF); 1993.

Ministério da Saúde. Saúde da Família: Uma estratégia para a reorientação do modelo assistencial. Brasília (DF); 1997.

Ministério de Saúde. Secretaria de Assistência á Saúde. Manual de Organização da Atenção Básica. Brasília (DF); 1999.

Ministério da Saúde. Secretaria de Políticas de Saúde, Departamento de Atenção Básica. Cadernos de Atenção Básica. Programa de Saúde da Família. Brasília (DF); 2000. Caderno 1- Implantação da saúde da família.

Ministério da Saúde. Secretaria de Políticas de Saúde. Departamento de Atenção básica. Avaliação da implantação do programa de saúde da família em dez grandes centros urbanos. Brasília (DF); 2002.

Nicolas DH. Tempo, espaço e apropriação do território: rumo à fragmentação na mundialização? In: Santos et al., organizadores. Teritório. Globalização e Fragmentação. $4^{\circ}$ edição. São Paulo: HUCITEC; 1998.

Novaes HM. Ações Integradas nos Sistemas Locais de saúde SILOS - Análise Conceitual e Apreciação de Programas Selecionados na América Latina- PROAHSA - Programas 
Avançados em Administração Hospitalar da saúde- Organização Panamericana de Saúde. São Paulo: Editora Pioneira; 1990.

Novaes HMD. et al. Novos Modelos Assistênciais à Saúde- Avaliação do PSF- Qualis - no Município de São Paulo. Relatório de Pesquisa Centro de Estudos CEALAG. São Paulo; 1999.

Paim JN. A reforma sanitária e os modelos assistenciais: a organização dos serviços de saúde: sessão temática. In: Anais do II Congresso de Epidemiologia: 1994; Belo Horizonte: COOPMED/ABRASCO. p. 189-9

Paim JN. Bases conceituais da reforma sanitária brasileira., In : Fleury S, organizador. Saúde e Democracia. A luta do CEBES. São Paulo: Ed. Lemos; 1997. p. 11-24.

Paula Souza GH. Conferência: Themas para Diretores de Saúde Pública dos Estados. In: Primeiro Congresso Brasileiro de Hygiene; 1923 outubro 1-7; Rio de Janeiro: Officinas Graphicas da Inspetoria de Demographia Sanitária; 1927. p.45-61.

Peduzzi M, Palma JJL. A equipe de saúde. In: Scraiber LB, Nemes MIB, Gonçalves RBM, organizadores. Saúde do Adulto Programas e Ações na Unidade Básica. $2^{\text {a. }}$ edição. São Paulo: HUCITEC; 2000.

Peduzzi M. Equipe Multiprofissional de saúde: conceito e tipologia. Revista de Saúde Pública $2001 ; 35$ (1) jan/2004.

Prefeitura Municipal de Saúde. Secretaria Municipal de Saúde. Manual da atenção básica no município de Vitória. Vitória (ES); 1999.

- Pichon - Riviere E. Teoria do Vínculo. São Paulo : Ed Martins Fontes; 2000 
Rodrigues Neto E. A Via do Parlamento. In : Fleury S, organizadora. Saúde e Democracia. A luta do CEBES. São Paulo: Editora Lemos; 1997. p. 11-24.

Santos M. A natureza do espaço. $2^{\circ}$ edição. São Paulo: HUCITEC; 1997

Santos M. O espaço cidadão. $4^{\circ}$ edição. São Paulo: Editora Nobel; 1998.

Schraiber LB. O médico e seu mercado de trabalho- Limites da liberdade. São Paulo: HUCITEC; 1993.

Schraiber LB. Políticas Públicas e Planejamento nas Práticas de Saúde. Saúde em Debate 1995; 47

Schraiber LB, Nemes MIB. Processo de trabalho e avaliação de serviços em saúde. Cadernos FUNDAP 1996; 19: 106-21.

Secretaria Municipal da Saúde de Vitória. Projeto Integrar. Vitória unida pela saúde- projeto de Implantação do sistema Integrado de serviços de saúde- SISS na Região de São Pedro. Vitória (ES); 2000.

Senna MCM. Cohn MM. Modelo Assistêncial e estratégia de Saúde da Família no nível local: análise de uma experiência. Ciência e Saúde Coletiva. 2002; 7 (3): 523-535.

Senna MCM. Equidade e políticas: algumas reflexões sobre o Programa Saúde da Família. Cadernos de Saúde Pública 2002; 18 (sup.): 203- 211.

Serapione M. Métodos qualitativos e quantitativos na pesquisa social em saúde: algumas estratégias para a integração. Ciência e Saúde Coletiva 2000; 5 ( 1): 187-92. 
Silva júnior AG. Modelos Tecnoassistenciais em saúde - O debate no campo da Saúde Coletiva. São Paulo: HUCITEC; 1998.

Unglert CVS. Territorialização em Saúde: A conquista do espaço local enquanto prática do planejamento ascendente. Parte da tese apresentada à Faculdade de Saúde Pública da Universidade de São Paulo para concurso de Livre-Docência. São Paulo 1995. (doação da autora)

Vaitsman J. Saúde, Cultura e Necessidades . In: Fleury S, organizadora. Saúde: Coletiva? Questionando a Impotência do Social. Rio de Janeiro: Relume-Dumará; 1992. p. 157-173.

Vasconcellos MP. Reflexões sobre a Saúde da Família . In : Mendes Vilaça E., organizador. Organização da Saúde no Nível Local. São Paulo: HUCITEC; 1998. p .155-172. 
ANEXOS 
ANEXO 1

REGIÕES E SERVIÇOS DE SAÚDE DE VITÓRIA

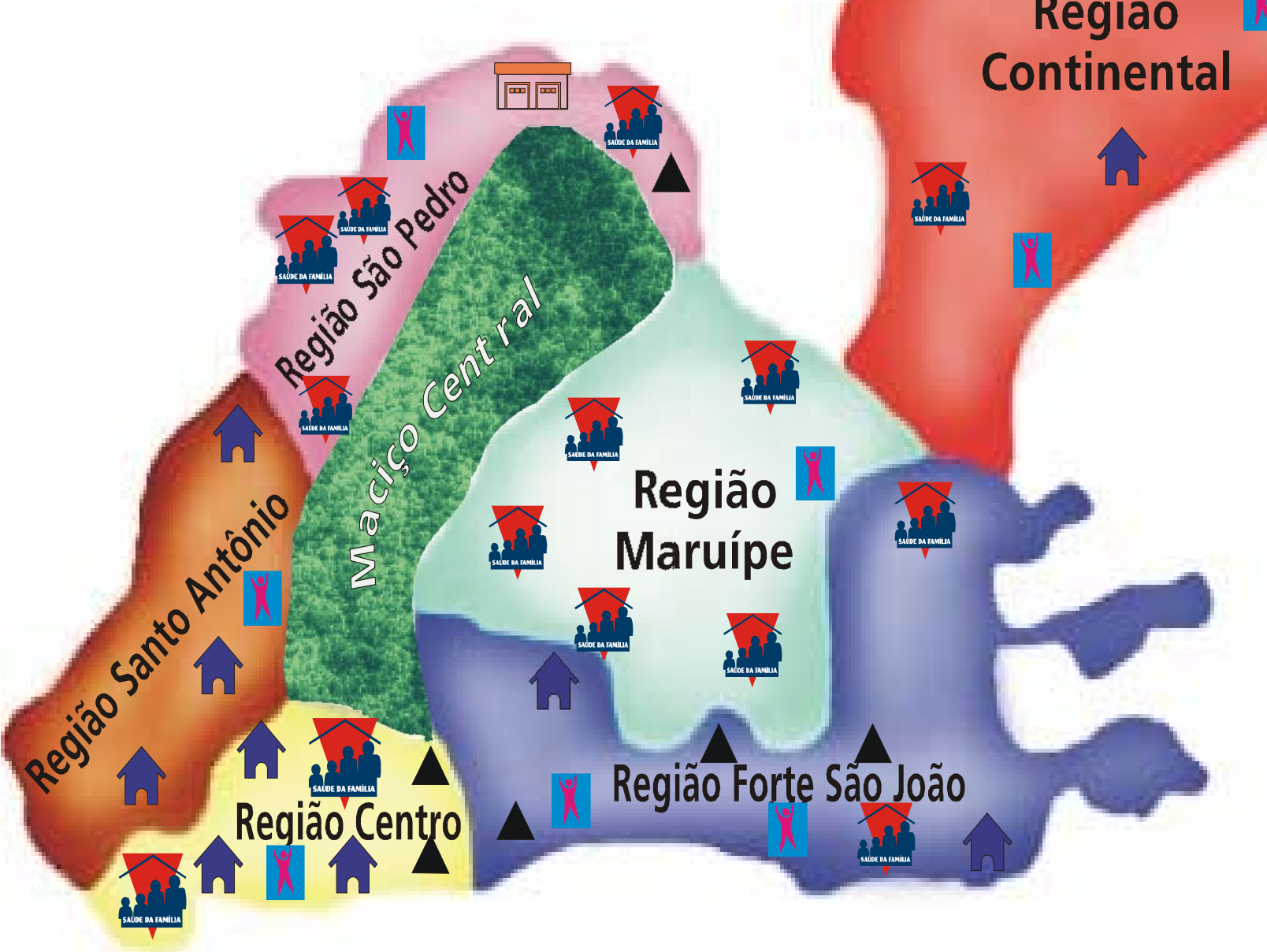

Fonte: SEMUS/NPD/2004 
ANEXO 2

BAIRROS DA REGIÃo DE SÃO PEDRO

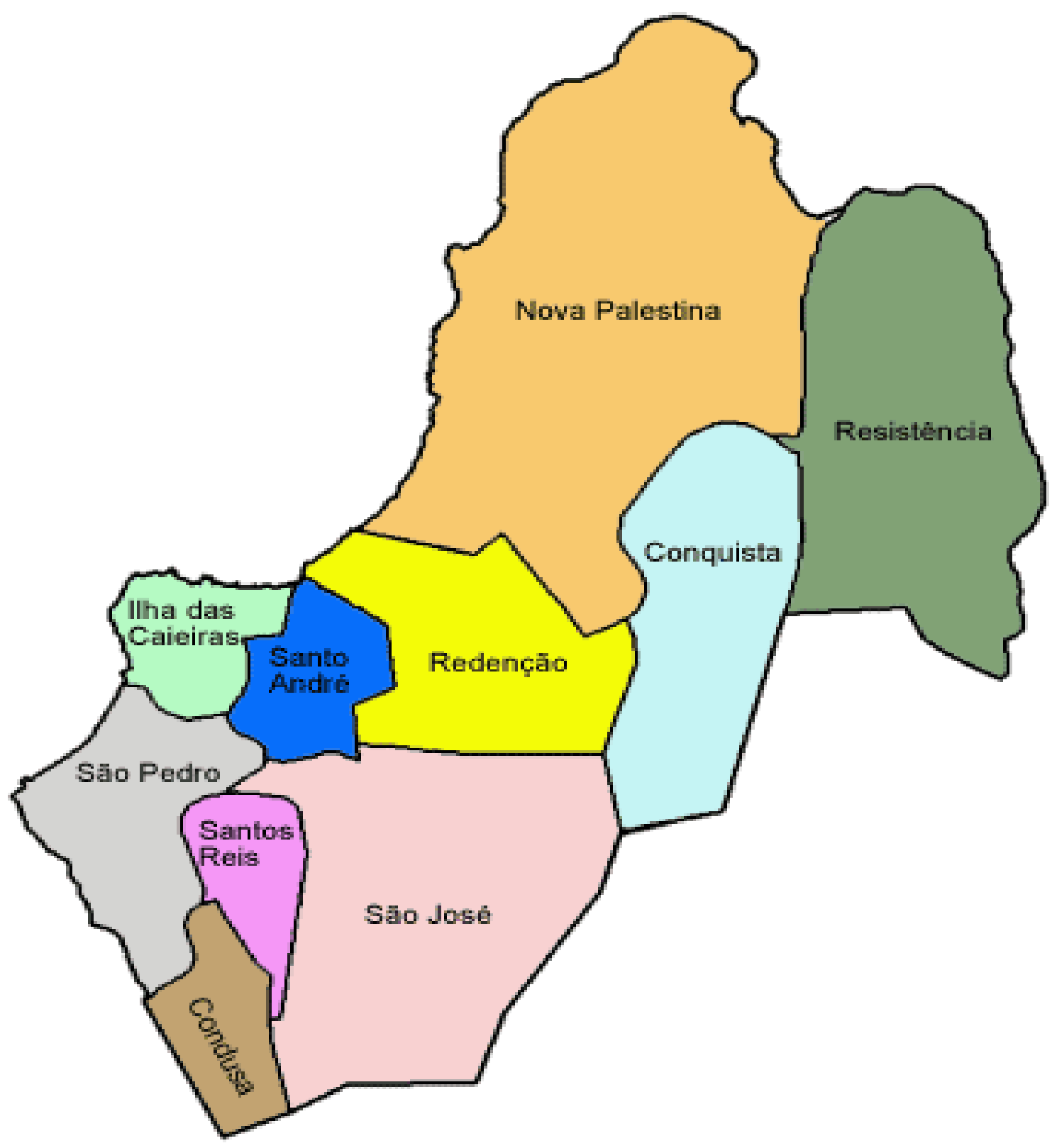

fonte: www.vitória.es.gov.hr 


\section{ANEXO 3 \\ TERMO DE CONSENTIMENTO LIVRE E ESCLARECIDO}

Tendo em vista as diretrizes éticas da Resolução 196/96 do Conselho Nacional do Ministério da Saúde, pelo presente termo de consentimento, declaro que fui informado (a) de forma clara e por escrito, sobre os objetivos da pesquisa "A prática médica no PSF e sua contribuição para a mudança de modelo tecnoassistencial em saúde: limites e possibilidades", bem como sua relevância, tendo os profissionais médicos a liberdade de participação ou recusa. e que o anonimato será mantido se assim o desejarem.

Como participante da pesquisa serei entrevistado pelo pesquisador com o auxílio de um gravador e com agendamento prévio.

Dessa forma livre e devidamente esclarecido (a) aceito participar da pesquisa da mestranda Luiza Maria de Castro Augusto Alvarenga, CRM/ ES 3375, CI 02927722-5, tel: 33240825, aluna de Mestrado da Faculdade de Saúde Pública da Universidade de São Paulo- FSP/USP.

Vitória, de de 


\begin{abstract}
ANEXO 4
ROTEIRO DE ENTREVISTA

Nome:

Tempo de formado

Especialidade

Tempo de atuação no PSF

Locais de trabalho anteriores (PSF ou não)
\end{abstract}

\title{
Perguntas norteadoras.
}

1. Por que optou por trabalhar no PSF?

2. Que atividades desenvolve no PSF?

a. Consulta médica. Quem atende? Quem agenda? Quais as prioridades?

b. Visita domiciliária. Porque decide fazer uma visita? O que você faz na visita. Contribui para a saúde do paciente ou da família?

c. Palestras: quando? Para quê?

3. Conhece os pacientes?

4. Conhece as famílias do território?

5. O que você planeja para as famílias do território?

6. Como é conduzido o acompanhamento de uma criança desnutrida?

7. Como são encaminhados os problemas onde o limite da atuação médica é evidente?

8. Em que tipo de problema você é solicitado pela comunidade? Você alterou sua prática pela reivindicação comunitária?

9. Como se dá o planejamento das atividades da equipe?

10. O que dá satisfação no trabalho do PSF ? e insatisfação? 
